\title{
Kritická místa kurikula na základní škole pohledem mezinárodního šetření TIMSS a českých učitelů - poznatky z fyziky ${ }^{1}$
}

\author{
Jiří Kohout a , Marie Mollerová b, Pavel Masopust c , Lukáš Feřt d, \\ Jan Slavík ${ }^{\mathrm{e}}$
}

\begin{abstract}
a, b, c, d Západočeská univerzita v Plzni, Fakulta pedagogická, Katedra matematiky, fyziky a technické výchovy, Oddělení fyziky

e Západočeská univerzita v Plzni, Fakulta pedagogická, Katedra pedagogiky
\end{abstract}

Redakci zasláno 30. 7. 2018 / upravená verze obdržena 11.12. 2018 /

/ k uveřejnění přijato 5. 2. 2019

\begin{abstract}
Abstrakt: Cílem studie je zjistit, které úlohy zařazené do obsahové domény fyzika v šetření TIMSS v letech 1995, 1999 a 2007 byly problematické (ve smyslu slabých výsledků českých žáků ve srovnání s mezinárodním průměrem) a odhadnout př́činy této problematičnosti a následně stanovit kritická místa fyzikálního kurikula na základní škole. $V$ úvodní části je stručně představen dosavadní výzkum týkající se kritických míst kurikula, která jsou definována jako oblasti, ve kterých se při vyučování a učení vyskytují problémy s fyzikálními koncepty. Rovněž je realizována hierarchizace těchto konceptů. Dále jsou stanovena kritéria, na jejichž základě bylo identifikováno celkem 19 problematických úloh zadaných v TIMSS, a rovněž je prezentován výzkum mající za cíl odhalit příčiny jejich kritičnosti (analýza kurikulárních dokumentů a rozhovory s 31 učiteli fyziky). Pro tři vybrané úlohy jsou vytvořeny sémanticko-logické sítě umožňující hlubší náhled na mentální procesy skryté za řešením těchto úloh žáky. Bylo identifikováno šest kritických míst fyzikálního kurikula na ZŠ a ukázáno, že prŕćčiny kritičnosti je třeba hledat jak v psychodidaktické, tak v ontodidaktické oblasti. Prezentované výsledky naznačují, že je třeba věnovat pozornost identifikovaným kritickým místům fyzikálního kurikula, speciálně pak vývoji technik umožňujících překonat kritičnost těchto míst. Příčiny kritičnosti, stejně jako hierarchizace příslušných fyzikálních konceptů, by měly být vzaty do úvahy při reformě kurikulárních dokumentů.
\end{abstract}

Klíčová slova: kritická místa kurikula, mezinárodní srovnávací šetření, TIMSS, rozhovory, problematické úlohy, učitelé fyziky, sémanticko-logické sítě

1 Výzkum byl podpořen projektem OP VVV Didaktika - Člověk a př́roda A (CZ.02.3.68/0.0/ /0.0/16 011/0000665).

https://doi.org/10.5817/PedOr2019-1-5 
V posledních letech je věnována značná pozornost problematice kurikula vnímaného obvykle jako „obsah vzdělávání, který zahrnuje veškeré zkušenosti, které žáci získávají ve škole a v činnostech ke škole se vztahujících, zejména jejich plánování, zprostředkovávání a hodnocení“ (Maňák, 2007). V souvislosti s aktuálními potřebami výzkumu i školské praxe pak roste význam tzv. kritických míst kurikula chápaných jako oblasti, kde žáci selhávají (Rendl \& Vondrová, 2014). Tato problematika byla v posledních letech intenzivně studována u matematiky (Rendl et al., 2013; Rendl \& Vondrová, 2014; Vondrová et al., 2017), v didaktice př́rodních věd jí však dosud nebyla věnována odpovídající pozornost na národní ani na mezinárodní úrovni.

Kritická místa kurikula se zásadně projevují v kvalitě výuky, a je proto žádoucí je identifikovat a analyzovat. K identifikaci kritických míst je možné přistoupit mnoha různými způsoby. Jedním z nich je opřít se o výsledky mezinárodních šetření př́rodovědné gramotnosti, jimž je v posledních letech přikládán značný význam nejen v převažujícím směru pedagogického výzkumu, ale i celkově ve společnosti. ${ }^{2}$ Výhodou šetření je možnost objektivního srovnání výsledků žáků z České republiky s dalšími státy (Straková, 2011), což dává při vhodné práci se získanými daty šanci najít témata, která u nás z nějakého důvodu dělají žákům znatelně než ve státech se srovnatelnou vzdělávací situací. Důvody pro tento rozdíl mohou být různé: nezohlednění věkové přiměřenosti, nedostatek vhodných pomůcek, nevyhovující zpracování tématu $\mathrm{v}$ př́íslušných učebnicích, slabá didaktická příprava budoucích učitelů apod. Samotná analýza výsledků mezinárodních srovnání nám však jen stěží může prozradit, proč je to či ono téma kritické. K tomu je potřeba užít další výzkumné metody, jako jsou třeba analýzy kurikulárních dokumentů a učebnic, rozhovory s učiteli a žáky, rozbory prací žáků, analýzy videozáznamů pořízených během hodin zaměřených na dané téma apod.

Vhodným př́istupem, který může přinést výsledky prospěšné pro vzdělávací praxi, je tak dle našeho názoru kombinace (1) sekundárních analýz mezinárodních šetření umožňujících empiricky identifikovat kritická místa v rámci zkoumané populace a (2) návazných kvalitativních výzkumných metod majících za cíl stanovit příčiny jejich kritičnosti. Samotný kvantitativní přístup

\footnotetext{
Bereme v úvahu mnohdy relevantní kritiku testování částí pedagogické komunity (srov. Kaščák \& Pupala, 2011; Štech, 2015). Zároveň však pokládáme testování a testové položky za výtečný podklad pro analýzu kritických míst kurikula, protože poskytují hromadné údaje o žákovské volbě řešení a umožňují s relativně velkou přesností posuzovat rozdíly mezi správným a nesprávným rozhodnutím (srov. Rendl \& Vondrová, 2014).
} 
totiž neposkytuje dost informací pro reálnou podporu kvality výuky v praxi, protože nepřináší vhled do sémantické a logické výstavby testových úloh, jež se odráží v žákově úspěšném řešení.

O dosažených výsledcích žáků v oblasti fyziky, spadající do přírodovědné gramotnosti, se dozvídáme z mezinárodních srovnávacích výzkumů TIMSS (Trends in International Mathematics and Science Study) a PISA (Programme for International Student Assessment). Ačkoliv PISA je pravděpodobně známější a zveřejnění jejích výsledků vzbuzuje větší mediální a společenský zájem, pro oborově specifické sekundární analýzy výsledkử ${ }^{3}$ je v českém prostředí častěji užíván TIMSS. S ohledem na zaměření našeho výzkumu do oblasti kritických míst se proto budeme dále zabývat právě šetřením TIMSS. To je detailně popsáno (včetně časového vývoje výsledků českých žáků) např. v knize Strakové (2016) nebo v článku Tomáška a Mandíkové (2009). Pro účely této studie spatřujeme přínos uvedeného šetření v možnosti identifikovat na základě výsledků žáků v ČR a dalších státech problematické úlohy a následně je provázat s kritickými místy kurikula. K tomu je však třeba uvedené pojmy lépe teoreticky vymezit.

\section{$1 \quad$ Kritická místa jako problém s koncepty}

Jednoduchá definice kritického místa jako oblasti, v níž žáci nedosahují očekávaných výsledků, nám pro hlubší úvahy nemůže postačovat, protože zamlčuje klíčové didaktické téma: souvztažnost mezi subjektivními příčinami problémů u žáků a oborovou relevancí problému. Přesněji terminologicky řečeno, didaktické porozumění kritickým místům vyžaduje analýzu souvislostí mezi psychodidaktickým hlediskem, orientovaným od žáka k oboru, a hlediskem ontodidaktickým, směřujícím od oboru k žákovi (srov. Janík \& Slavík, 2009).

Selhání žáků při řešení fyzikálních úloh může být například přímým důsledkem jejich matematické nedostatečnosti.

V takovém případě může jít o přenos kritického místa z matematiky (např́íklad nezvládnutí tématu „kalorimetrická rovnice“ může být důsledkem kritičnosti rovnic v matematice jako takových) a uvedená oblast vůbec nemusí

Zde nemáme na mysli pravidelně Českou školní inspekcí zveřejňované sekundární analýzy pro obě uvažovaná šetření, ale spíše studie zaměřené na rozbory jednotlivých skupin oborově specifických úloh, jako jsou např. práce Rendla a Vondrové (2014) či Mandíkové a Trny (2011). 
být problematická z pohledu samotného fyzikálního porozumění obsahu. Podstatným faktorem může být i to, jak je dané místo kurikula důležité pro návaznou problematiku, jinými slovy, jaká je jeho pozice v hierarchii (školské) fyziky. Zjednodušeně řečeno, pokud žáci nezvládají na odpovídající úrovni téma „bimetal“, je to kvalitativně jiný typ problému, než když vůbec neporozumí gravitaci či setrvačnosti.

S cílem zohlednit jak ontodidaktické, tak psychodidaktické hledisko jsme v našich předchozích studiích (Kohout et al., 2018; Mentlík et al., 2018) rozvinuli teorii chápající kritická místa kurikula jako zdroj problémů ve vztahu prekonceptů žáků ke zvládnutí konceptů 4 příslušného oboru (zde fyziky) $\mathrm{s}$ ohledem na hierarchii těchto konceptů. Naše úvahy vycházely na jedné straně (v širších teoretických a filozofických kontextech) z poznatků instrumentálního realismu sumarizovaných v práci Kvasze (2015), na straně druhé (s ohledem na didaktiku oboru) z tzv. konceptuální fyziky (Hewitt, 1971; Beichner, 2009). Konceptuální fyzika je odpovědí na mnoho desetiletí dominantní matematizacie školské fyziky a klade důraz na fundamentální porozumění základním fyzikálním konceptům místo mechanického užívání formálních matematických operací v kontextu fyzikálních úloh.

Kurikulum chápeme jako časově vázanou ${ }^{5}$ strukturu konceptů, přičemž kritické místo kurikula je takový koncept, který je v dané struktuře nevhodně umístěn (např. $\mathrm{z}$ hlediska přiměřenosti vzhledem k věku či kurikulární návaznosti) nebo u něj selhává realizace v rámci samotné výuky (např. v důsledku nevhodného řešení v učebnicích, špatného provázání s dříve probraným učivem ${ }^{6}$ či nedostatku vhodných experimentů, popř. materiálního vybavení potřebného $\mathrm{k}$ jeho realizaci). Kritická místa tak v souladu se zaměřením této studie na relativní výsledky českých žáků v úlohách TIMSS chápeme jako ta místa kurikula, kde existuje prokazatelný potenciál ke zlepšení (např. díky změnám v kurikulu, vytvoření nových učebních materiálů apod.).

4 Koncept je obsahová jednotka, která je zakotvená v jazyce (jako pojem či termín), ale zahrnuje nejenom jazykové aktivity, ale všechny intencionální operace spojené s daným obsahem. Subjektivním protějškem konceptu je prekoncept. Detailněji je tato problematika řešena v knize Slavíka a kol. (2017, s. 156).

5 V tom smyslu, že jednotlivé koncepty jsou ve škole probírány v určité části daného ročníku a je na ně typicky vymezen určitý počet hodin.

6 Například u tématu „hustota“ se ve fyzice v 6. třídě často (a to i v učebnicích) odvolává na aspekty dané problematiky probírané dříve v přírodovědě. Analýza učebnic přírodovědy i př́slušných ŠVP však ukázala, že tyto aspekty se zde vůbec nevyskytují. Může tak docházet k situacím, že učitel fyziky má hned zkraje mylnou představu o předchozích znalostech žáků. 
Uvedli jsme, že kritická místa kurikula mají svůj zdroj v problémech žáků s koncepty oboru. Proto je pro didaktickou práci s kritickými místy kurikula důležité rozlišovat typ konceptu podle povahy jeho působnosti na spojnici mezi oborem a výukou. Typy konceptů lze hierarchicky upořádat, protože rozsah jejich působnosti, jak uvnitř (vzdělávacího) oboru nebo celé oblasti (např. přírodní vědy), tak ve výuce, je různě velký. $Z$ hlediska této hierarchie rozlišujeme (Kohout et al., 2018; Mentlík et al., 2018):

- Klíčové koncepty - základní stavební kameny oboru zasahující do všech přírodovědných disciplín. Relevantní zahraniční výzkumy užívají v tomto kontextu přiléhavý termín průřezové koncepty (crosscutting concepts) a zařazují do této nejvyšší kategorie typicky následující koncepty (Lancorová, 2014): tvar; prríčina a následek; mechanismus a vysvětlení; velikost, proporce a kvantita; systém a model systému; struktura a funkce; stabilita a změna; hmota a energie.

- Substantivní koncepty - těmto obsahovým složkám oboru ukotveným v objektivní realitě ve fyzice rámcově odpovídají fyzikální veličiny. V uvedené oblasti můžeme přirozeně vysledovat další hierarchii, když např. koncept momentu síly je typicky níže než koncept síly (moment síly totiž charakterizuje otáčivé účinky síly, jež tvoří pouze jeden z možných typů silových účinků).

- Organizační koncepty - zde jde v zásadě o vztahy mezi substantivními veličinami, jejichž prostřednictvím se zároveň substantivní koncepty váží ke konceptům klíčovým. Těmto vztahům ve fyzice přirozeně odpovídají fyzikální zákony. Do této kategorie tedy spadají např. Newtonovy pohybové zákony, které propojují substantivní koncepty pohyb a síla a zároveň je dávají do souvislosti s klíčovými koncepty, jako je směr či př́čćina a následek.

- Aplikační koncepty - tato úroveň je pro fyziku specifická (Kohout et al., 2018), ve vztahu ke kritickým místům je však zcela relevantní. Poměrně často totiž netkví zásadní problém v samotné fyzikální veličině, resp. vztahu mezi veličinami, ale spíše v aplikaci na konkrétní systém či geometrii ${ }^{7}$.

\footnotetext{
Např. v optice na základní škole není (dle zkušeností autorů i vyjádření některých učitelů zapojených v níže popisovaném výzkumu) jako kritický vnímán substantivní koncept světlo či organizační koncepty zákon odrazu či zákon lomu světla, ale jako velmi obtížné je vnímáno zobrazování kulovými zrcadly či čočkami. Přitom nejde o nic jiného než o aplikaci uvedených organizačních konceptů na určitou geometrii či tvar.
} 
Kritická místa se mohou nacházet kdekoliv v uvedené hierarchii, mohou k nim tedy patřit i níže postavené aplikační koncepty. Př́kladem jsou situace, kdy žáci mají zásadní problém aplikovat pro ně dobře pochopitelný fyzikální zákon na určitou specifickou geometrii (např. z důvodu vysokých nároků na prostorovou představivost či grafické znázornění situace). To kritická místa zásadním způsobem odlišuje od tzv. klíčových míst kurikula jako uzlových bodů ve struktuře konceptů, jež hrají zásadní roli při tzv. spirálovém pojetí kurikula (Dvořák, 2009). Tato klíčová místa má smysl hledat ve vysoce postavených substantivních či organizačních konceptech (Kohout et al., 2018).

V této studii se budeme zabývat konkrétními učebními úlohami z mezinárodního srovnání TIMSS, jež byly na základě srovnání s dalšími státy identifikovány jako problematické. Ke každé úloze přitom budeme přiřazovat koncept mající určitou pozici v hierarchii dle výše uvedeného rozložení. To nám umožní danou úlohu lépe uchopit, stanovit příčiny její problematičnosti a rovněž identifikovat $\mathrm{v}$ návaznosti na problematické úlohy přímo kritická místa kurikula. Vycházíme přitom z předpokladu, že úlohy v šetření TIMSS jsou vytvořeny natolik kvalitně, že jejich výsledky jsou průkazné ve vztahu ke zvládnutí př́slušného konceptu či alespoň některého jeho podstatného aspektu. ${ }^{8}$

\section{Cíl studie}

Jak již bylo uvedeno, analýze výsledků českých žáků ve fyzice v mezinárodních srovnáních byla v minulosti věnována značná pozornost nejen ve sdělovacích prostředcích, ale i v odborné literatuře. Většina publikovaných studií se však zaměřovala na popis globálních trendů a nebyla $v$ jejich rámci provedena didaktická analýza jednotlivých úloh. Pokud pak již byly v souvislosti s výzkumem miskoncepcí jednotlivé problematické úlohy vymezeny (např. Mandíková \& Trna, 2011), nebyla věnována pozornost analýze příčin jejich kritičnosti.

V souvislosti s výše uvedeným je proto cílem této studie detailněji didakticky analyzovat úlohy zadané ve fyzikální části mezinárodního srovnání TIMSS z let 1995, 1999 a 2007, vytipovat problematické úlohy, objasnit příčiny

8 K jednomu konceptu lze vytvořit větší množství učebních úloh, a i v rámci šetření TIMSS se někdy objevovaly různě formulované úlohy patřící na stejné místo v dané hierarchii. Proto je nutné se při přechodu od problematických úloh ke kritickým místům zaměřit na všechny uvažované úlohy a diskutovat případy, kdy některá úloha patřící $\mathrm{k}$ danému konceptu byla identifikována jako problematická, zatímco jiná nikoliv. 
jejich kritičnosti a provést zobecnění od konkrétních úloh směrem ke kritickým místům kurikula. Výzkumnou otázku pak můžeme formulovat následovně: Jaká jsou kritická místa fyzikálního kurikula na ZŠ a v čem spočívají prríčiny jejich kritičnosti?

\section{Metodologie}

Metodologicky se prezentovaný výzkum opírá o smíšený design zahrnující kvantitativní analýzu výsledků úloh z mezinárodního šetření TIMSS, rozhovory s učiteli fyziky na ZŠ a o analýzu obsahu učebnic a školních vzdělávacích programů. Z hlediska metod sběru dat byl využit polostrukturovaný rozhovor a sekundárních data byla získána z veřejně dostupných zdrojů. Data z rozhovorů byla zpracována s využitím softwaru ATLAS.ti, sekundární data poté pomocí programu Microsoft Excel. V další části uvedeme detailní informace o postupu stanovení problematických úloh na základě sekundární analýzy výsledků z šetření TIMSS (část 3.1) a rovněž bližší informace o výzkumu zaměřeném na příčiny kritičnosti úloh (část 3.2).

\subsection{Stanovení problematických úloh}

Zásadní metodologickou výzvou bylo stanovení kritérií pro výběr problematických jednotek, a to z celkové množiny 99 analyzovaných originálních úloh patřících do obsahové domény fyzika a zadaných $\mathrm{v}$ rámci šetření TIMSS v letech 1995, 1999 a 2007, které byly do konce roku 2017 uvolněny organizátory. S uvážením metodologického přístupu užitého $\mathrm{v}$ podobně zaměřené studii týkající se kritických míst ve výuce matematiky (Rendl \& Vondrová, 2014) a specifik výuky fyziky na českých základních školách jsme stanovili následující dvě kritéria:

Kritérium 1: daná úloha musí odpovídat učivu, které již mají žáci v době konání mezinárodního šetření TIMSS typicky probráno - tedy učivu probíranému v období od 6. ročníku do konce prvního pololetí 8. ročníku (výzkum TIMSS probíhá vždy na jaře v 8. ročníku). Pro stanovení toho, zda úloha splňuje uvedené kritérium, jsme provedli analýzu učebnic fyziky ${ }^{9}$ pro druhý

$\overline{9}$ V současné době existuje celkem šest sad učebnic fyziky pro ZŠ majících ministerskou doložku, přičemž posloupnost učiva je v těchto učebnicích různá. V této studii jsme vyšli ze tří tradičních učebnic od nakladatelství Fraus, Prométheus a SPN, které byly podle předchozích výzkumů (Höfer, Půlpán, \& Svoboda, 2005) v českých školách v době konání uvažovaných srovnání TIMSS nejrozšířenější. 
stupeň základních škol a ŠVP deseti náhodně vybraných základních škol v Plzeňském kraji. Ke splnění kritéria bylo zapotřebí, aby byl příslušný tematický celek probírán v uvedeném časovém rozpětí dle všech uvažovaných zdrojů. To zaručuje, že př́činou problematičnosti dané úlohy není skutečnost, že se mnozí čeští žáci s tímto učivem v době konání testování ještě ne-

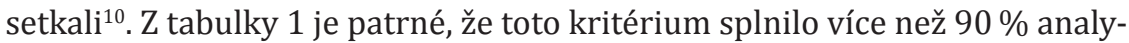
zovaných úloh.

Tabulka 1

Výběr problematických úloh na základě uvedených kritérií

\begin{tabular}{llll}
\hline & TIMSS 1995 & TIMSS 1999 & TIMSS 2007 \\
\hline Celkový počet úloh v šetření & 40 & 41 & 42 \\
\hline Počet úloh splňující kritérium 1 & 38 & 39 & 39 \\
\hline Počet úloh splňující kritérium 1 a 2A & 5 & 6 & 5 \\
\hline Počet úloh splňující kritérium 1 a 2B & 0 & 3 & 2 \\
\hline Výběr zkoumaných úloh splňující kritérium 1 a 2A & S012004 & S012022 & S032403 \\
(mezinárodní kód) & S012022 & S012047 & S032273 \\
& S012029 & S022017 & S042196 \\
& K10 & S022043 & S042173B \\
& Q12 & S012029 & S032024 \\
\hline Výběr zkoumaných úloh splňující kritérium 1 a 2B & & S022035 & \\
(mezinárodní kód) & & S012009 & S042061 \\
& & S022048 & S042244A \\
\hline
\end{tabular}

Pozn.: Kurzívou jsou označeny úlohy opakující se ve více ročnících.

Kritérium 2: V rámci tohoto kritéria jsme vyžadovali, aby čeští žáci měli $\mathrm{v}$ příslušné úloze slabé výsledky v mezinárodním srovnání. Jako přirozené se jeví srovnání s mezinárodním průměrem, ten však může být výrazně ovlivněn zeměmi, kde je jiná posloupnost učiva apod. Proto jsme 2 . kritérium rozdělili na dvě dílčí kritéria $\mathrm{A}$ a $\mathrm{B}$, přičemž k zařazení do výzkumu stačilo, aby úloha splnila jedno z nich:

A) testové úlohy, v nichž čeští žáci dosáhli nižší úspěšnosti, než byl mezinárodní průměr ${ }^{11}$;

10 Nebo alespoň nesetkali během studia fyziky na 2. stupni ZŠ, případný přesah z učiva př́rodovědy na 1 . stupni jsme zde vzhledem k zaměření studie neuvažovali.

11 V rámci obsahové domény fyzika jako celku jsme byli ve všech realizacích TIMSS znatelně nad mezinárodním průměrem. 
B) testové úlohy, v nichž sice čeští žáci dosáhli vyšší úspěšnosti, než byl mezinárodní průměr, ale zároveň dopadli výrazně hůře (alespoň o 15 procentních bodů) než žáci v některém z evropských států zvlášt' vybraných ke srovnání na základě společných kulturně-historických rysů a zjištěných podobností ve fyzikálním kurikulu. V roce 2007 jsme české žáky srovnávali s Anglií, Itálií a Slovinskem, v roce 1999 s Anglií, Finskem, Slovinskem a Slovenskem a v roce 1995 s Anglií, Rakouskem, Německem, Slovenskem a Slovinskem. V žádné z uvažovaných zemí není výuce fyziky do okamžiku realizace šetření TIMSS věnováno více času než v ČR, příčinou rozdílu by tak neměla být větší časová dotace.

Z tabulky 1 jsou patrné počty a mezinárodní označení úloh, které splnily alespoň jedno z uvedených dílčích kritérií. Uvedených 19 originálních úloh (úlohy značené jako S012022 a S012029 naplnily uvedená kritéria hned při dvou realizacích šetření - v letech 1995 a 1999) jsme pak detailně analyzovali s ohledem na př́činy jejich problematičnosti.

\subsection{Identifikace prríčin u problematických úloh a určení kritických míst}

Ve snaze porozumět př́činám toho, proč jsou dané úlohy z pohledu mezinárodního srovnání problematické, jsme provedli další zkoumání. To zahrnovalo polostrukturované rozhovory s 31 učiteli fyziky (17 žen a 14 mužũ) na základních školách z různých regionů České republiky. Jednalo se o všechny učitele zapojené do projektu Didaktika A - Člověk a př́roda, který realizují univerzity v Plzni, Olomouci, Ústí nad Labem a Hradci Králové. Kritériem pro zapojení do projektu byla aprobovanost učitele fyziky ${ }^{12}$ a předem deklarovaný zájem o problematiku kritických míst kurikula. Průměrná délka pedagogické praxe participantů byla 13,2 roku (rozpětí 1-33 let, výběrová směrodatná odchylka 10,8 roku, medián 9 let). Rozhovory byly zaměřeny právě na problematiku kritických míst ve výuce fyziky, identifikaci prŕčin jejich kritičnosti a strategie učitelů při překonávání těchto míst, přičemž specifické výzkumné otázky (SVO) pro tyto rozhovory byly stanoveny v souladu s obecnými doporučeními Švaříčka a Šed'ové (2007) následovně:

SVO1: Jaká témata probíraná typicky v 6. a 7. ročníku ZŠ pokládají učitelé fyziky na ZŠ za kritická a proč?

12 Ve smyslu definice uvedené v práci Mollerové a kol. (2018). 
SVO2: Co si učitelé fyziky na ZŠ představují pod slovním spojením kritické téma?

SV03: Jak vnímají učitelé fyziky na ZŠ vztah matematiky a fyziky v kontextu kritických témat?

SVO4: Jaké strategie uplatňují učitelé fyziky na ZŠ při vypořádávání se s kritickými tématy?

Rozhovory byly se souhlasem účastníků nahrány, přepsány a následně exportovány do programu ATLAS.ti. V tomto programu pak byly cíleně vyhledány a analyzovány části rozhovorů ${ }^{13}$ týkající se prř́čin kritičnosti jednotlivých míst označených učiteli. Učitelé nebyli v rámci rozhovoru přímo konfrontováni s výsledky šetření TIMSS ani s konkrétními problematickými úlohami. Partikulárním cílem však bylo zjistit, do jaké míry se subjektivní náhled učitelů shoduje se zjištěními z mezinárodního srovnání. Učitelé během rozhovorů rovněž vybírali ze seznamu 80 základních analytických jednotek, probíraných typicky v 6. a 7. ročníku ZŠ, nejvýše 10 položek, které chápou z fyzikálního hlediska jako kritické. Uvedený seznam položek byl sestaven na základě výše popsané obsahové analýzy nejčastěji používaných učebnic fyziky pro 6. a 7. třídu. Pozornost jsme věnovali rovněž hodinové dotaci fyziky v jednotlivých ročnících základních škol v Plzeňském a Karlovarském kraji, jež byla zjištěna celkem u 179 škol v uvedených regionech na základě údajů z výročních zpráv, resp. telefonických rozhovorů s řediteli těchto škol. Detaily jsou uvedeny v naší předchozí studii (Mollerová et al., 2018).

\section{$4 \quad$ Zadání problematických úloh}

V této části studie stručně představíme zadání a relativní četnosti odpovědí u českých žáků (převzaté z analýz publikovaných Ústavem pro informace ve vzdělávání) pro 19 identifikovaných problematických úloh. Zadání zde není uvedeno doslovně, je z něj však patrná podstata problému. Doslovné zadání je možné najít pro rok 2007 v publikaci Tomáška a kol. (2009), pro rok 1999 v publikaci kolektivu autorů z Ústavu pro informace ve vzdělávání (ÚIV, 2001) a pro rok 1995 v publikaci Palečkové, Tomáška a Strakové (1997).

13 Nebylo tedy provedeno kódování celého rozhovoru, ale v podstatě obsahová analýza vybraných pasáží majících bezprostřední dopad do oblasti vnímaných příčin kritických míst. Detailní rozbor kvalitativních dat získaných od učitelů bude předmětem dalšího výzkumu. 


\subsection{Problematické úlohy}

Úloha 1 (mezinárodní označení S032273, úloha zadána v roce 2007)

Šlo o úlohu zaměřenou na problematiku elektromagnetu, v níž měli žáci uveden obrázek hřebíku, kolem něhož byl omotán izolovaný drát připojený k baterii. Žáci pak měli rozhodnout, co se stane s hřebíkem, pokud bude drátem procházet proud.

Varianty možných odpovědí a jejich zastoupení u českých žáků byly následující:
A) hřebík se roztaví $(1,7 \%)$
B) hřebíkem bude procházet elektrický proud (44,2\%)
C) hřebík se stane magnetem $(22 \%)^{14}$
D) se hřebíkem se nestane nic $(31,2 \%)^{15}$

Úloha 2 (mezinárodní označení S022035, úloha zadána v roce 1999) Jednalo se o úlohu zaměřenou na magnetické pole a magnetické indukční čáry. Na obrázku byl magnet s vyznačenými póly, který byl pilkou rozř́źznut na tři části. Žáci měli za úkol vyznačit do prázdných políček póly magnetu na prostředním kousku po rozř́iznutí. Správně vyznačilo polaritu 39,6\% žáků, 52,1\% uvedlo polaritu opačně a zbytek bud' otázku nezodpověděl, nebo uvedl nesmyslné řešení (dva jižní póly apod.).

Úloha 3 (mezinárodní označení S032024, úloha zadána v roce 2007)

Zadání úlohy zaměřené na přeměny energie bylo jednoduché: Která z těchto energetických přeměn odpovídá procesům v kapesní baterce, pokud ji rozsvítí$m e$ ? Možnosti odpovědí a př́íslušné relativní podíly byly následující:
A) elektrická $\rightarrow$ mechanická $\rightarrow$ světelná $(53,1 \%)$
B) chemická $\rightarrow$ mechanická $\rightarrow$ světelná $(8,6 \%)$
C) chemická $\rightarrow$ elektrická $\rightarrow$ světelná $(26,8 \%)$
D) jaderná $\rightarrow$ elektrická $\rightarrow$ světelná $(8,6 \%)$

14 Správné odpovědi jsou u uzavřených úloh s výběrem z možností označeny kurzivou.

15 Součet relativních četností odpovědí není $100 \%$, protože někteří žáci nechali otázku bez jakékoliv odpovědi. 
Úloha 4 (mezinárodní označení S012047, úloha zadána v roce 1999)

Žáci měli v této úloze rozhodnout, odkud původně pochází energie nashromážděná v potravě, kterou lidé jedí a z níž získávají energii.

Možnosti odpovědí a jejich příslušné relativní četnosti byly následující:

A) z průmyslových hnojiv (1,9\%)

B) ze Slunce $(18 \%)$

C) z vitaminů $(44,3 \%)$

D) z půdy (35\%)

Úloha 5 (mezinárodní označení S012022, úloha zadána v letech 1995 a 1999) V této úloze měli žáci rozhodnout, jakému ději odpovídá sled přeměn:

chemická energie $\rightarrow$ tepelná energie $\rightarrow$ kinetická energie (a nevyužité teplo) Žáci mohli volit z těchto odpovědí ( $v$ závorce jsou uvedeny odpovídající četnosti v ČR po řadě pro roky 1995 a 1999):
A) je zapnuta kapesní svítilna (10,4 \%; 7,6\%)
B) hoří svíčka (21\%; 19,8\%)
C) spaluje se benzín pro pohon auta $(57,1 \% ; 54,6 \%)$
D) elektrický proud pohání chladničku $(8,5 \% ; 15,1 \%)$

Úloha 6 (mezinárodní označení Q12, úloha zadána v roce 1995)

Jednalo se o otevřenou úlohu, kdy si dvě děti hrály s jinak stejnými svítilnami, přičemž chlapec měl baterku bez reflektoru a dívka s reflektorem. Žáci měli rozhodnout, ze které žárovky dopadne více světla na zed' vzdálenou $5 \mathrm{~m}$ a své rozhodnutí vysvětlit. Správně odpovědělo v ČR 34,5 \% žáků, nejčastější chybnou odpovědí bylo to, že uvedli jedno z dětí, ale již nijak nevysvětlili svoji volbu.

Úloha 7 (mezinárodní označení S042196, úloha zadána v roce 2007)

$\mathrm{V}$ této otevřené úloze bylo úkolem žáků vysvětlit, proč se $\mathrm{v}$ domácnosti používá častěji paralelní než sériové zapojení v elektrickém obvodu. Akceptovatelné vysvětlení dokázalo podat jen 16,1\% českých žáků, zbytek uvedl vysvětlení chybné (50,5 \%) či žádné (33,3 \%). 
Úloha 8 (mezinárodní označení S042173B, úloha zadána v roce 2007)

Podstatou úlohy bylo rozhodnout, zda se při změně skupenství z kapalného na plynné změní hmotnost, či nikoliv. Správnou odpověd' v souladu se zákonem zachování hmotnosti uvedlo jen 37,2\% českých žáků, $59 \%$ chybně uvedlo, že se hmotnost změní, zbytek neodpověděl vůbec.

Úloha 9 (mezinárodní označení S032403, úloha zadána v roce 2007)

$\mathrm{V}$ této úloze měli žáci rozhodnout, které z vybraných tvrzení o částicích kapalin ve srovnání s částicemi plynu je správné. Nabízené varianty odpovědí a jejich relativní četnosti byly následující:
A) částice kapaliny jsou pomalejší a jsou od sebe dál (11,2 \%)
B) částice kapaliny jsou rychlejší a jsou od sebe dál (14,5 \%)
C) částice kapaliny jsou pomalejší a jsou k sobě blíž (40,1\%)
D) částice kapaliny jsou rychlejší a jsou k sobě blíž (30,9\%)

Úloha 10 (mezinárodní označení S042061, úloha zadána v roce 2007)

Tato úloha byla zaměřena na mikroskopické fungování teplotní roztažnosti. Obrázek znázorňoval uspořádání částic v kovu předtím, než je kov zahříván:

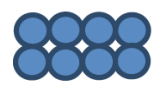

Otázka zněla, který z následujících obrázků znázorňuje uspořádání částic v kovu poté, co byl zahřát?

A)

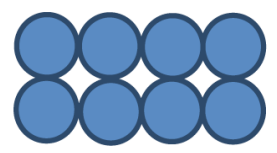

B)

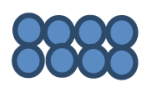


C)

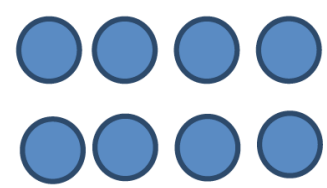

D)

\section{0 \\ 0000}

Možnost A) volilo 18,9\% žáků, možnost B) 17,9\%, C) 25,2\% a konečně D) 36,2 \% žáků.

Úloha 11 (mezinárodní označení S012009, úloha zadána v roce 1999)

Úkolem žáků v této úloze bylo určení předmětu s největší hustotou na základě hmotnosti a objemu uvedených předmětů. Žáci měli k dispozici následující tabulku:

\begin{tabular}{lll}
\hline Předmět & Hmotnost předmětu & Objem předmětu \\
\hline $\mathrm{W}$ & $11 \mathrm{~g}$ & $24 \mathrm{~cm}^{3}$ \\
\hline $\mathrm{X}$ & $11 \mathrm{~g}$ & $12 \mathrm{~cm}^{3}$ \\
\hline$Y$ & $5,5 \mathrm{~g}$ & $4 \mathrm{~cm}^{3}$ \\
\hline $\mathrm{Z}$ & $5,5 \mathrm{~g}$ & $11 \mathrm{~cm}^{3}$ \\
\hline
\end{tabular}

Předmět W měl největší hustotu dle 56,6 \% žáků, X uvedlo 6,5 \%, správnou odpověd' Y zvolilo 29,4 \% žáků a konečně předmět $\mathrm{Z}$ měl největší hustotu podle $4,4 \%$ žáků.

Úloha 12 (mezinárodní označení S022048, úloha zadána v roce 1999)

Úkolem žáků $v$ této otevřené úloze zaměřené na rozpínavost plynů bylo vysvětlit, proč balónky naplněné héliem v horkém letním dni po několika hodinách na slunci zvětší svůj objem. Správně odpovědělo 32,9 \% českých žáků, u ostatních bylo vysvětlení nedostatečné či žádné. 
Úloha 13 (mezinárodní označení S022268, úloha zadána v roce 1999)

$\mathrm{V}$ této otevřené úloze zaměřené na schopnost vysvětlovat vědecké experimenty bylo úkolem žáků uvést, co je možné zjistit pokusem, při němž studentka vzala dvě stejné nádoby a naplnila je stejným množstvím vody. $V$ jedné $\mathrm{z}$ nádob nechala rozpustit lžičku soli a poté obě tyto nádoby umístila do mrazáku. Následně obě nádoby sledovala každých 5 minut, dokud v jedné z nich nezmrzla voda. Správnou odpověd' (vliv příměsi na teplotu tuhnutí) uvedlo 54,1\% žáků.

\section{Úloha 14 (mezinárodní označení S022017, úloha zadána v roce 1999)}

Stroje A a B se používají k čerpání vody z řeky. V tabulce bylo uvedeno, jaký objem vody přečerpá každý stroj za jednu hodinu a jaká je spotřeba benzínu u obou strojů.

$$
\begin{array}{ll}
\text { Objem vody přečerpané } & \text { Benzín spotřebovaný } \\
\text { za } 1 \text { hodinu (v litrech) } & \text { za } 1 \text { hodinu (v litrech) }
\end{array}
$$

\begin{tabular}{lll}
\hline Stroj A & 1000 & 1,25 \\
\hline Stroj B & 500 & 0,5 \\
\hline
\end{tabular}

Žáci měli určit, který ze strojů je účinnější při přeměně energie z benzínu na práci, a svoji odpověd' měli zdůvodnit. Správný výběr (stroj B) a vysvětlení uvedlo jen 29,7 \% českých žáků, dalších téměř 34 \% žáků sice správně uvedlo stroj B, ale svoji volbu nezdůvodnilo. Zbytek uvedl nesprávně stroj A či vůbec neodpověděl.

\section{Úloha 15 (mezinárodní označení S022043, úloha zadána v roce 1999)}

V této otevřené úloze chlapec zapnul ve svém pokoji kapesní svítilnu a posvítil s ní na zed' ze vzdálenosti jednoho metru tak, aby vznikl malý kruh světla. Potom posvítil kapesní svítilnou na strop ze vzdálenosti dvou metrů tak, aby vznikl větší kruh světla. Žáci měli určit, zda dopadá na strop více či méně světla než na zed’ a svoji odpověd' zdůvodnit. Správný závěr (dopadá stejně světla) a vysvětlení podalo pouze $22,9 \%$ žáků, téměř $20 \%$ uvedlo, že na strop dopadne méně světla a více než 50 \% naopak tvrdilo, že na strop dopadne světla více (typicky s vysvětlením, že je tam větší světelný kruh). 
Úloha 16 (mezinárodní označení S012029, úloha zadána v letech 1995 a 1999) V této úloze žáci věděli, že destička umístěná ve vzdálenosti $20 \mathrm{~cm}$ od žárovky vyvolá na stěně vzdálené dalších $20 \mathrm{~cm}$ od destičky stín o velikosti $10 \mathrm{~cm}$. Měli určit, jaká bude délka strany stínu po posunu stěny o dalších $40 \mathrm{~cm}$ směrem od žárovky. K dispozici měli náčrtek situace. Možné varianty odpovědí (a jejich četnosti po řadě v roce 1995 a 1999) byly následující:
A) $5 \mathrm{~cm}(15,9 \% ; 11,2 \%)$
B) $10 \mathrm{~cm}(10,9 \% ; 13,7 \%)$
C) $15 \mathrm{~cm} \mathrm{(9 \% ;11,4 \% )}$
D) $20 \mathrm{~cm}(59,2 \% ; 55,9 \%)$

Úloha 17 (mezinárodní označení S012004, úloha zadána v roce 1995)

$\mathrm{V}$ této úloze měli žáci rozhodnout, proč za denního světla vidí člověk, který stojí v místnosti, z okna ven, ale člověk, který stojí venku před domem, dovnitř oknem nevidí.

Jednalo se o úlohu s volbou z následujících odpovědí ( $\mathrm{v}$ závorce četnosti v ČR):

A) uvnitř místnosti není dostatek světla, který by osvětloval osobu stojící uvnitř dоти $(69,4 \%)$

B) sluneční paprsky nemohou projít přes okno domu dvakrát (7,3\%)

C) vnější světelné paprsky neprojdou skrze okno dovnitř domu (11,4 \%)

D) sluneční světlo není tak silné jako jiné zdroje světla $(11,1 \%)$

Úloha 18 (mezinárodní označení K10, úloha zadána v roce 1995)

Žáci měli v této otevřené úloze popsat alespoň jeden způsob, jak dokázat přítomnost vzduchu, když je bezbarvý, bez zápachu a bez chuti. Uspělo jen 26,1 \% českých žáků, 59 \% žáků uvedlo nedostatečné či zcela chybné vysvětlení, zbytek se nepokusil o řešení úlohy vůbec.

Úloha 19 (mezinárodní označení S042244A, úloha zadána v roce 2007)

Jednalo se o úlohu, v níž měli žáci přiřadit k objektům užitým u reálné páky sloužící ke zvedání břemen při stavbě Cheopsovy pyramidy části páky dle klasického školského obrázku užívaného v učebnicích apod. Uspělo 
pouze 20,6 \% českých žáků, zbytek udělal v přiřazování alespoň jednu chybu (61,6 \%) či neodpověděl vůbec.

\section{$5 \quad$ Výsledky studie}

Ve výsledkové části nejprve uvedeme souhrnnou tabulku ${ }^{16}$ obsahující příčiny problematičnosti jednotlivých úloh odhadnuté na základě detailního rozboru dostupných informací (část 5.1). Poté provedeme u trojice vybraných úloh analýzu odhadovaných myšlenkových postupů žáků při řešení problému technikou sémanticko-logických sítí (část 5.2). Na závěr přejdeme na základě rozhovorů s učiteli a obsahové analýzy dokumentů k samotné identifikaci kritických míst kurikula (část 5.3).

\subsection{Souhrn př́ŕčin neúspěšnosti u problematických úloh}

V souhrnné tabulce 2 jsou uvedeny koncepty odpovídající dané úloze, průměrná úspěšnost u českých žáků, mezinárodní průměr a údaj pro nejúspěšnější srovnávanou zemi. Rovněž je zahrnuta identifikace hlavních příčin problematičnosti úlohy na základě konsenzu vzešlého $\mathrm{z}$ analýzy úlohy autorským kolektivem, analýzy kurikulárních dokumentů a vyjádření učitelů fyziky na ZŠ v polostrukturovaných rozhovorech (a interpretace těchto vyjádření autory studie).

Tabulka 2

Přehled přičin neúspěšnosti problematických úloh

\begin{tabular}{|c|c|c|c|}
\hline $\begin{array}{l}\text { Číslo úlohy } \\
\text { a odpovídající } \\
\text { koncept }\end{array}$ & $\begin{array}{l}\text { Průměr } \\
\text { v ČR / } \\
\text { mezinárodní } \\
(\%)\end{array}$ & $\begin{array}{l}\text { Průměr } \\
\text { v nejlepší } \\
\text { srovnávané } \\
\text { zemi (\%) }\end{array}$ & Hlavní identifikované přričiny kritičnosti \\
\hline $\begin{array}{l}\text { 1. Elektromagnet } \\
\text { (aplikační } \\
\text { koncept) }\end{array}$ & $22,0 / 36,9$ & 55,9 (Anglie) & $\begin{array}{l}\text { - umístění abstraktního tématu v kurikulu } \\
\text { (konec 6. ročníku } \rightarrow \text { časová tíseň, ztráta } \\
\text { motivace) } \\
\text { - nepochopení klíčové souvislosti elektřiny } \\
\text { a magnetismu } \\
\text { - formální uchopení na základě klíčových } \\
\text { slov bez přemýšlení nad fyzikálním } \\
\text { mechanismem či nepochopení pojmu } \\
\text { izolovaný drát }\end{array}$ \\
\hline
\end{tabular}

16 Do tabulky zahrneme rovněž relativní četnosti správných odpovědí u jednotlivých úloh v rámci mezinárodního srovnání. Tyto údaje byly převzaty ze souhrnů výsledků dostupných na https://timss.bc.edu/. 


\begin{tabular}{|c|c|c|c|}
\hline $\begin{array}{l}\text { Číslo úlohy } \\
\text { a odpovídající } \\
\text { koncept }\end{array}$ & $\begin{array}{l}\text { Průměr } \\
\text { v ČR / } \\
\text { mezinárodní } \\
(\%)\end{array}$ & $\begin{array}{l}\text { Průměr } \\
\text { v nejlepší } \\
\text { srovnávané } \\
\text { zemi (\%) }\end{array}$ & Hlavní identifikované př́ičiny kritičnosti \\
\hline $\begin{array}{l}\text { 2. Póly magnetu, } \\
\text { magnetické } \\
\text { indukční čáry } \\
\text { (organizační } \\
\text { koncepty) }\end{array}$ & $39,6 / 49,1$ & $\begin{array}{l}54,4 \\
\text { (Slovinsko) }\end{array}$ & $\begin{array}{l}\text { - nepochopení rozdílu mezi elektrickým } \\
\text { a magnetickým polem (žáky uváděná } \\
\text { odpověd' odpovídala elektrickému poli) } \\
\text { - k řešení potřeba abstraktní znázornění } \\
\text { pole pomocí magnetických indukčních } \\
\text { čar } \\
\text { - magnetismus problematický kvůli } \\
\text { zařazení v kurikulu (konec 6. ročníku } \rightarrow \\
\text { časová tíseň, ztráta motivace) }\end{array}$ \\
\hline $\begin{array}{l}\text { 3. Přeměna } \\
\text { energie } \\
\text { (organizační } \\
\text { koncept) }\end{array}$ & $26,8 / 34,9$ & 60,7 (Anglie) & $\begin{array}{l}\text { - nepropojení poznatků dvou tematických } \\
\text { celků probíraných odděleně } \\
\text { - formální uchopení úlohy na základě } \\
\text { klíčového slova (plochá baterie vztažena } \\
\text { automaticky k elektrické energii) } \\
\text { - nesprávné vztažení pojmu mechanická } \\
\text { energie k pohybu nabitých částic } \\
\text { v elektrickém poli (nezvládnutá } \\
\text { terminologie) }\end{array}$ \\
\hline $\begin{array}{l}\text { 4. Energie } \\
\text { (substantivní } \\
\text { koncept) }\end{array}$ & $18 / 24,5$ & 41,8 (Anglie) & $\begin{array}{l}\text { - vyžaduje propojení poznatků z různých } \\
\text { disciplín (biologie - fotosyntéza, chemie } \\
\text { - energie reakce, fyzika - sluneční } \\
\text { energie) } \\
\text { - svádí k řešení na základě } \\
\text { zpopularizované, ale povrchní a nepřesné } \\
\text { souvislosti (vitamíny dodávají energii, } \\
\text { která je v potravě - nejčastější nesprávná } \\
\text { odpověd') }\end{array}$ \\
\hline $\begin{array}{l}\text { 5. Přeměna } \\
\text { energie } \\
\text { (organizační } \\
\text { koncept) }\end{array}$ & $\begin{array}{l}57,1 / 58,3 \\
\text { (r. 1995) } \\
54,6 / 58,7 \\
\text { (r. 1999) }\end{array}$ & $\begin{array}{l}76 \text { (Anglie - } \\
\text { r. 1995) }\end{array}$ & $\begin{array}{l}\text { - nezvyklá terminologie užitá v české verzi } \\
\text { (kinetická místo pohybová } \rightarrow \text { neznalost } \\
\text { užitého pojmu a obecně problém } \\
\text { s terminologií zmiňovaný v jiném } \\
\text { kontextu v práci Štěpánika a Slavíka } \\
\text { z roku 2017) } \\
\text { - nesprávné vztažení pojmu kinetické } \\
\text { (pohybové) energie k neuspořádanému } \\
\text { pohybu (terminologie) }\end{array}$ \\
\hline
\end{tabular}




\begin{tabular}{|c|c|c|c|}
\hline $\begin{array}{l}\text { Číslo úlohy } \\
\text { a odpovídající } \\
\text { koncept }\end{array}$ & $\begin{array}{l}\text { Průměr } \\
\text { v ČR / } \\
\text { mezinárodní } \\
(\%)\end{array}$ & $\begin{array}{l}\text { Průměr } \\
\text { v nejlepší } \\
\text { srovnávané } \\
\text { zemi (\%) }\end{array}$ & Hlavní identifikované příčiny kritičnosti \\
\hline $\begin{array}{l}\text { 6. Šíření světla } \\
\text { (organizační } \\
\text { koncept) }\end{array}$ & $34,5 / 46,7$ & 65,4 (Anglie) & $\begin{array}{l}\text { - v českém prostředí atypická úloha } \\
\text { (šíŕení světla pojímáno spíše teoreticky } \\
\text { a odtrženě od jednoduchých aplikací } \\
\text { braných jako samozřejmé) } \\
\text { - umístění tématu v kurikulu (konec } \\
\text { 7. ročníku } \rightarrow \text { časová tíseň, ztráta } \\
\text { motivace) } \\
\text { - malý důraz na experimentování } \\
\text { s jednoduchými pomůckami v dané } \\
\text { oblasti fyziky (optika) }\end{array}$ \\
\hline $\begin{array}{l}\text { 7. Aplikace } \\
\text { elektrických } \\
\text { obvodů } \\
\text { (aplikační } \\
\text { koncept) }\end{array}$ & $16,1 / 17,5$ & 38,1 (Anglie) & $\begin{array}{l}\text { - v českém prostředí atypická úloha } \\
\text { (vyžaduje provedení analýzy výhod } \\
\text { a rizik) } \\
\text { - nutnost propojit poznatek z běžného } \\
\text { života (různé jističe pro různé okruhy } \\
\text { v domácnosti) s učivem ze školy } \\
\text { (odtržení výuky od zkušenosti) } \\
\text { - v učebnicích explicitně nezmiňováno, } \\
\text { pravděpodobně bráno jako samozřejmost }\end{array}$ \\
\hline $\begin{array}{l}\text { 8. Změny } \\
\text { skupenství } \\
\text { (organizační } \\
\text { koncept), } \\
\text { hmotnost } \\
\text { (substantivní } \\
\text { koncept) }\end{array}$ & $37,2 / 43,2$ & $\begin{array}{l}48,2 \\
\text { (Slovensko) }\end{array}$ & $\begin{array}{l}\text { - nezvládnutá aplikace poznatku z chemie } \\
\text { (zákon zachování hmotnosti) do fyziky } \\
\text { v důsledku nepochopení souvislosti } \\
\text { mezi chemickou reakcí a skupenskou } \\
\text { přeměnou } \\
\text { - nezdůraznění zachování hmotnosti } \\
\text { při skupenských přeměnách ve fyzice } \\
\text { (bráno jako samozřejmost či spoléhání se } \\
\text { na chemii) }\end{array}$ \\
\hline $\begin{array}{l}\text { 9. Skupenství } \\
\text { (substantivní } \\
\text { koncept) }\end{array}$ & $40,1 / 40,8$ & 61,6 (Anglie) & $\begin{array}{l}\text { - vyžaduje určit mikroskopické vlastnosti } \\
\text { na základě makroskopických } \\
\text { - některé ve školách užívané modely } \\
\text { mohou být zavádějící (nerozlišují } \\
\text { rychlosti pohybu částic u plynu } \\
\text { a kapaliny) } \\
\text { - úloha není zcela přesně zadána, daly by } \\
\text { se najít kombinace a vnější podmínky, } \\
\text { u kterých by uvedená správná odpověd' } \\
\text { nemusela platit }\end{array}$ \\
\hline
\end{tabular}




\begin{tabular}{|c|c|c|c|}
\hline $\begin{array}{l}\text { Číslo úlohy } \\
\text { a odpovídající } \\
\text { koncept }\end{array}$ & $\begin{array}{l}\text { Průměr } \\
\text { v ČR / } \\
\text { mezinárodní } \\
(\%)\end{array}$ & $\begin{array}{l}\text { Průměr } \\
\text { v nejlepší } \\
\text { srovnávané } \\
\text { zemi }(\%)\end{array}$ & Hlavní identifikované př́ičiny kritičnosti \\
\hline $\begin{array}{l}\text { 10. Teplotní } \\
\text { roztažnost } \\
\text { (organizační } \\
\text { koncept) }\end{array}$ & $34,0 / 36,2$ & 54 (Anglie) & $\begin{array}{l}\text { - velmi problematická konstrukce otázky } \\
\text { na základě modelu tuhých koulí } \\
\text { - rozpor s modely krystalových mřížek } \\
\text { běžně užívanými ve školách (viz část 5.2) } \\
\text { - nutnost propojit makroskopickou změnu } \\
\text { s procesy na mikroskopické úrovni, v ČR } \\
\text { se typicky neprovádí na ZŠ ani na SŠ } \\
\text { (roztažnost jen makroskopicky) }\end{array}$ \\
\hline $\begin{array}{l}\text { 11. Hustota } \\
\text { (substantivní } \\
\text { koncept) }\end{array}$ & $28,3 / 29,4$ & 46,4 (Anglie) & $\begin{array}{l}\text { - matematická nedostatečnost žáků } \\
\text { (přenos kritického místa - práce se } \\
\text { zlomky - z matematiky) } \\
\text { - vyžaduje pochopení dosti abstraktní } \\
\text { veličiny hustota (otázka vhodnosti } \\
\text { zařazení již v 6. ročníku ZŠ) }\end{array}$ \\
\hline $\begin{array}{l}\text { 12. Rozpínavost } \\
\text { plynů } \\
\text { (organizační } \\
\text { koncept) }\end{array}$ & $32,9 / 25,8$ & 48,7 (Finsko) & $\begin{array}{l}\text { - vyžaduje propojení poznatků ze školy } \\
\text { s běžnou zkušeností (nafukovací lehátko } \\
\text { na slunci zvětšuje objem), tj. odtržení } \\
\text { školy od zkušenosti } \\
\text { - ve škole užívané vysvětlení na základě } \\
\text { pohybu molekul velmi abstraktní (zvolilo } \\
\text { jen } 0,5 \% \text { ), intuitivnější makroskopické } \\
\text { vysvětlení pomocí souvislosti tlaku, } \\
\text { objemu a teploty se učí až na SŠ (i tak } \\
\text { zvolilo } 32,4 \% \text { ) }\end{array}$ \\
\hline $\begin{array}{l}\text { 13. Tuhnutí } \\
\text { (organizační } \\
\text { koncept) }\end{array}$ & $54,1 / 39,7$ & $\begin{array}{l}72,8 \\
\text { (Slovensko) }\end{array}$ & $\begin{array}{l}\text { - vyžaduje propojení poznatků ze školy } \\
\text { s běžnou zkušeností (solení silnic), } \\
\text { odtržení školy od zkušenosti } \\
\text { - vyžaduje schopnost navrhovat } \\
\text { experimenty a interpretovat jejich } \\
\text { výsledky, jež není v ČR mnohdy rozvíjena }\end{array}$ \\
\hline $\begin{array}{l}\text { 14. Účinnost } \\
\text { (organizační } \\
\text { koncept) }\end{array}$ & $29,7 / 30,7$ & $\begin{array}{l}50,4 \\
\text { (Slovensko) }\end{array}$ & $\begin{array}{l}\text { - matematická nedostatečnost žáků } \\
\text { (přenos kritického místa z matematiky) } \\
\text { - účinnost zde chápána ne jako zavedená } \\
\text { fyzikální veličina (vykonaná práce děleno } \\
\text { dodaná energie), ale poněkud atypicky } \\
\text { ve vztahu přečerpaného objemu vody } \\
\text { a spotřeby benzínu (atypická úloha) }\end{array}$ \\
\hline
\end{tabular}




\begin{tabular}{|c|c|c|c|}
\hline $\begin{array}{l}\text { Číslo úlohy } \\
\text { a odpovídající } \\
\text { koncept }\end{array}$ & $\begin{array}{l}\text { Průměr } \\
\text { v ČR / } \\
\text { mezinárodní } \\
(\%)\end{array}$ & $\begin{array}{l}\text { Průměr } \\
\text { v nejlepší } \\
\text { srovnávané } \\
\text { zemi }(\%)\end{array}$ & Hlavní identifikované př́ičiny kritičnosti \\
\hline $\begin{array}{l}\text { 15. Šíření světla } \\
\text { (organizační } \\
\text { koncept) }\end{array}$ & $22,9 / 24$ & $\begin{array}{l}32,4 \\
\text { (Slovensko) }\end{array}$ & $\begin{array}{l}\text { - v českém prostředí atypická úloha } \\
\text { (šíření světla pojímáno spíše teoreticky } \\
\text { a odtrženě od jednoduchých aplikací) } \\
\text { - umístění tématu v kurikulu (konec } \\
\text { 7. ročníku } \rightarrow \text { časová tíseň, ztráta } \\
\text { motivace) } \\
\text { - malý důraz na experimentování } \\
\text { s jednoduchými pomůckami v dané } \\
\text { oblasti fyziky (optika) }\end{array}$ \\
\hline $\begin{array}{l}\text { 16. Stín } \\
\text { a polostín } \\
\text { (organizační } \\
\text { koncept) }\end{array}$ & $\begin{array}{l}59.4 / 59,2 \\
\text { (r. } 1995) \\
55,9 / 59,6 \\
\text { (r. } 1999)\end{array}$ & $\begin{array}{l}62,3 \text { (Finsko } \\
\text { - r. 1999) }\end{array}$ & $\begin{array}{l}\text { - problematická návaznost na matematiku } \\
\text { (vyžaduje dosud neprobranou podobnost } \\
\text { trojúhelníků) } \\
\text { - malý důraz na experimentování } \\
\text { s jednoduchými pomůckami v dané } \\
\text { oblasti fyziky (optika) }\end{array}$ \\
\hline $\begin{array}{l}\text { 17. Šíření světla } \\
\text { (organizační } \\
\text { koncept) }\end{array}$ & $69,4 / 69,5$ & $\begin{array}{l}81,9 \\
\text { (Slovinsko) }\end{array}$ & $\begin{array}{l}\text { - v českém prostředí atypická úloha } \\
\text { (šíření světla pojímáno spíše teoreticky } \\
\text { a odtrženě od jednoduchých aplikací) } \\
\text { - umístění tématu v kurikulu (konec } \\
\text { 7. ročníku } \rightarrow \text { časová tíseň, ztráta } \\
\text { motivace) } \\
\text { - malý důraz na experimentování } \\
\text { s jednoduchými pomůckami v dané } \\
\text { oblasti fyziky (optika) }\end{array}$ \\
\hline $\begin{array}{l}\text { 18. Vzduch } \\
\text { (substantivní } \\
\text { koncept) }\end{array}$ & $26,1 / 33,1$ & 34,9 (Anglie) & $\begin{array}{l}\text { - nebyly uznávány časté odpovědi žáků } \\
\text { v souvislosti s dýcháním, potřebou } \\
\text { vzduchu pro hoření apod., vyžadována } \\
\text { byla odpověd' vyloženě se týkající } \\
\text { fyzikálních projevů (proudění, odpor } \\
\text { vzduchu apod.), což v zadání nebylo } \\
\text { specifikováno (tj. problematické } \\
\text { hodnocení úlohy) } \\
\text { - samotná existence vzduchu je brána } \\
\text { jako samozřejmost, není ve škole tolik } \\
\text { zdůrazňováno (jsou však uváděny } \\
\text { experimenty prokazující existenci } \\
\text { atmosférického tlaku vzduchu) }\end{array}$ \\
\hline $\begin{array}{l}\text { 19. Páka } \\
\text { (aplikační } \\
\text { koncept) }\end{array}$ & $20,6 / 19,1$ & 39,6 (Anglie) & $\begin{array}{l}\text { - vyžaduje propojení schématu užívaného } \\
\text { ve škole s využitím v praxi (odtržení } \\
\text { výuky od zkušenosti) }\end{array}$ \\
\hline
\end{tabular}




\subsection{Sémanticko-logické sítě pro vybrané problematické úlohy}

Řešení testové úlohy závisí na kvalitě mentálního schématu ${ }^{17}$, které má řešitel k dispozici (srov. Slavík et al., 2017, s. 184-189). Jinak řečeno, pokud žák při výběru odpovědi na testovou otázku přemýšlí (tj. nejde-li jen o náhodnou volbu), uplatňuje přitom své mentální schéma. Je zřejmé, že nikdo nemůže znát podobu mentálního schématu v mysli. To však není důležité, protože jeho subjektivní existence se projevuje praktikováním dovedností vytvářet, posuzovat a revidovat řešení př́islušných úloh. Mít určité mentální schéma tedy znamená mít schopnost provádět odpovídající činnosti (srov. Goodman \& Elginová, 2017, s. 118-119).

Vzhledem k tomu, že testové úlohy jsou konstruovány tak, aby měly logicky a významově korektní řešení a aby jejich chybná řešení bylo možné vysvětlit, lze každou variantu jejich řešení (správnou i chybnou) reprezentovat v podobě sémanticko-logické struktury („,sítě“). Konkrétní podoba sítě při řešení testových otázek se liší v závislosti na nabízené odpovědi. Ideální podoba sítě, která odpovídá bezchybnému řešení úlohy, musí být oborově správná a obecně platná. Ve vztahu k ní je pak možné vysvětlovat a zdůvodňovat korekce chybných řešení. Z toho vyplývá, že konstruování sémanticko-logických sítí testových otázek vychází z ontodidaktického hlediska: směřuje od oboru k žákovi. Je tedy úkolem pro experty - oborové didaktiky, kteří znají obor a zároveň jsou schopni na podkladě kvalifikovaného odhadu brát v úvahu žákovský př́istup k úloze.

Žákovská „subjektivní sít“" je tím víc ve shodě s expertním řešením, čím lépe žák úloze rozumí. Na její konkrétní podobu lze usuzovat jednak podle výsledku žákovského řešení (výběru odpovědi), jednak na podkladě zkoumání procesu řešení (pozorování žákova postupu, rozhovor se žákem). To je psychodidaktický př́stup (srov. Vondrová et al., 2017). Propojování ontodidaktického hlediska s hlediskem psychodidaktickým přináší úplný soubor didaktických informací o testové úloze.

17 Ve filozofii též konceptuální schéma (conceptual scheme; Strawson, 1997). Pojmem schéma se poukazuje na významovou a logickou strukturaci obsahu. Ta musí být izomorfní pro všechny tři základní způsoby existence obsahu: subjektivní (v paměti jedince), intersubjektivní (ve společné komunikaci), objektivní ( $\mathrm{v}$ aktuálním fyzickém světě). Proto je nutným základem jak pro porozumění světu, tak pro dorozumění se mezi lidmi. Pojem schéma v tomto pojetí má původ v tvarové psychologii, odkud se rozšířil do dalších oborů včetně didaktiky (Anderson \& Pearson, 1984; Hejný, 2008). 
$\mathrm{V}$ našem případě jsme se záměrně soustředili pouze na hledisko ontodidaktické. Jsme přesvědčeni o tom, že hlubší ontodidaktické zamyšlení nad podobami sémanticko-logických sítí v úlohách, které byly pro žáky obtížné, je nutnou první oporou pro pochopení miskoncepcí nebo dílčích překážek, které žákům bránily v úspěšném řešení. Proto zde z ontodidaktické pozice popisujeme sémanticko-logické sítě pro tři vybrané úlohy 1, 3 a 10.

Ve všech případech jde o uzavřené úlohy s výběrem správné odpovědi ze čtyř nabízených, což umožňuje rozkreslit sítě pro jednotlivé alternativy snáze než v př́ípadě otevřených úloh. $V$ prvních dvou př́padech se jedná o úlohy, u nichž byly zaznamenány velké rozdíly v četnosti odpovědí mezi jednotlivými možnostmi a zároveň byl jednoznačně nejčastěji vybrán jeden z distraktorů, což dává jistotu, že nepřevažují odpovědi zvolené zcela náhodně a má smysl se zabývat analýzou mentálních procesů probíhajících u žáků a vedoucích k volbě určité možnosti (v daných př́ípadech nejčastěji možnosti chybné). Úloha 10 pak byla vybrána jako ukázka toho, jak se zdánlivě jednoduchý problém ze základní školy týkající se představy žáků o mikroskopické realizaci dobře známého makroskopického jevu (teplotní roztažnosti) pohledem teoretické fyziky značně komplikuje a autory úlohy uváděná správná odpověd' může být velmi snadno zpochybněna.

Úloha 1 - Co se stane se hřebíkem omotaným izolovaným drátem, jimž prochází proud?

A) hřebík se roztaví

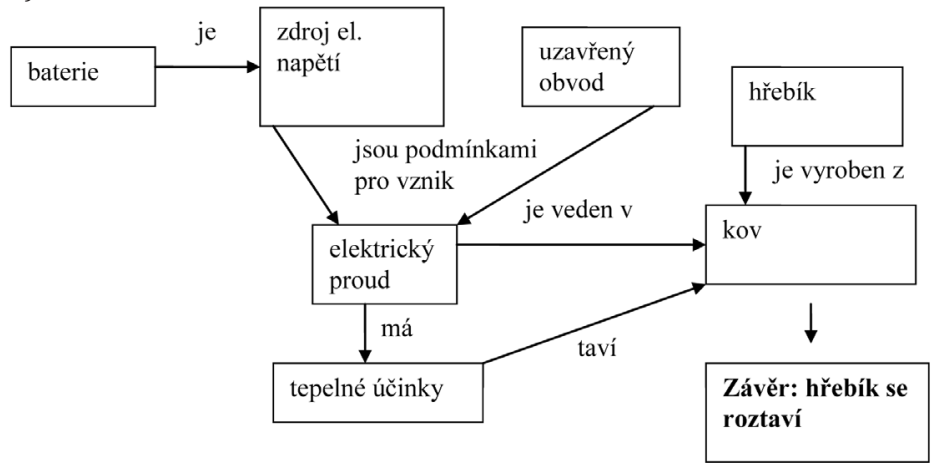


B) hřebíkem bude procházet proud

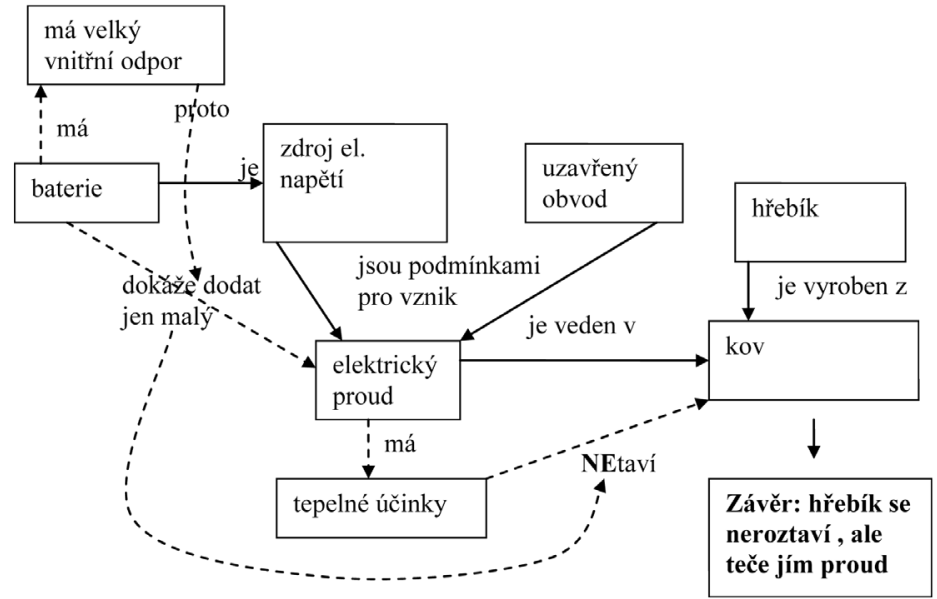

\section{Obrázek 1. Sémanticko-logická sít' pro úlohu 1 - odpovědi A), B)}

Pozn.: Přerušovaně jsou označeny spoje, které mohou a nemusí nastat, nemají však podstatný vliv pro řešení úlohy.

C) hřebík se stane magnetem (správná odpověd')

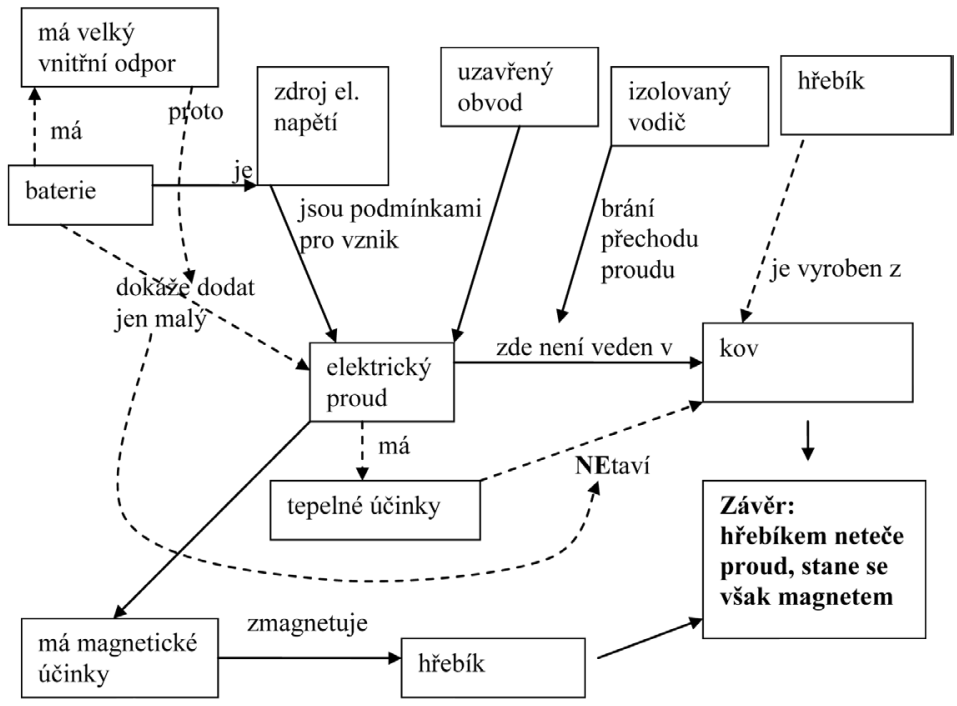




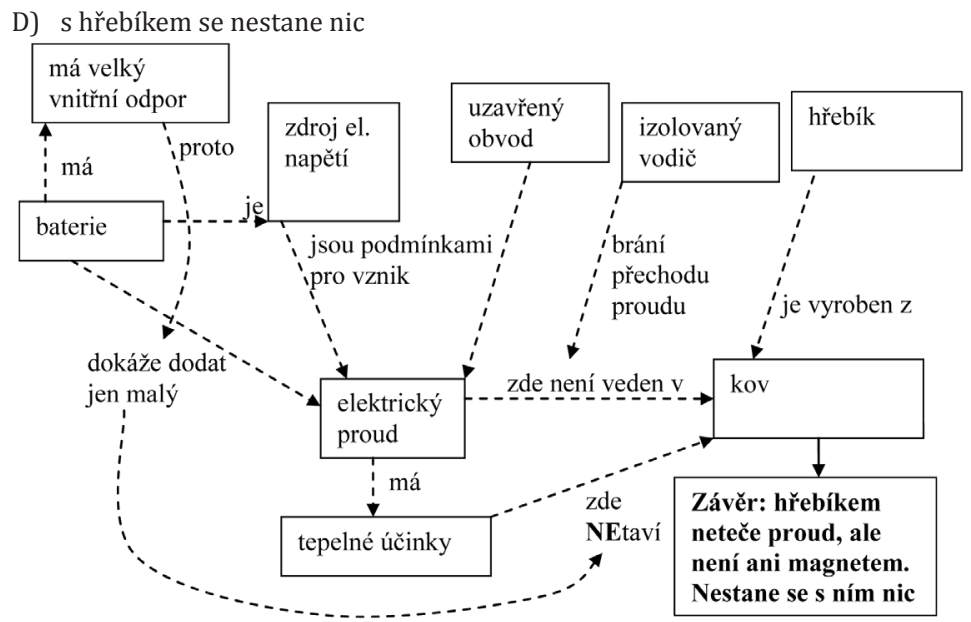

Obrázek 2. Sémanticko-logická sít' pro úlohu 1 - odpovědi C), D)

Pozn.: Přerušovaně jsou označeny spoje, které mohou a nemusí nastat, nemají však podstatný vliv pro řešení úlohy.

Komentář $k$ úloze 1: U možnosti A) žáci správně usoudili, že drátem bude procházet elektrický proud a prokázali znalost, že proud má i tepelné účinky a při velkých hodnotách dokáže i roztavit kov. Neuvědomili si však již, že baterie kvůli svému velkému vnitřnímu odporu nikdy nedokáže dodat tak velký proud, aby mohl roztavit hřebík. Proud se navíc z izolovaného drátu do hřebíku vůbec nemůže dostat. U nejčastěji volené možnosti, B), již žáci správně vyloučili to, že by proud $\mathrm{z}$ baterie mohl něco tavit, neuvědomili si však zásadní věc, že elektrony nemohou proběhnout izolací drátu a dostat se do hřebíku. U možnosti D) (tvrzení, že se s hřebíkem nestane nic) je více reálných možností, jak k ní mohli žáci dospět. Je celkem jisté, že si zde žáci neuvědomili existenci magnetických účinků elektrického proudu, nemůžeme však vědět, zda správně vyloučili vedení elektrického proudu hřebíkem z důvodu izolovaného drátu nebo zda si napřs vůbec neuvědomili, že v obvodě nějaký proud bude (třeba proto, že neznají funkci baterie či pojem izolovaný drát nesprávně chápou tak, že jím proud vůbec procházet nemůže). 
Úloha 3 - Která z těchto přeměn energie odpovídá procesům v baterce, pokud ji rozsvítíme?

A) elektrická - mechanická - světlo

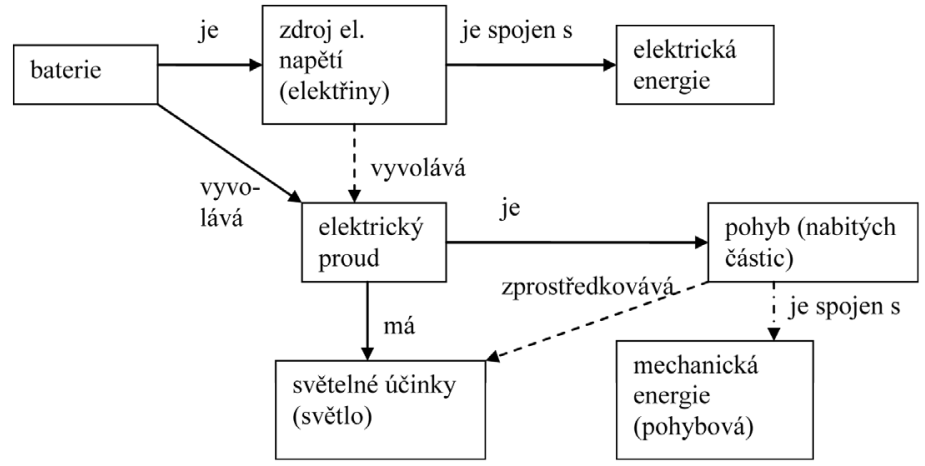

B) chemická - mechanická - světlo

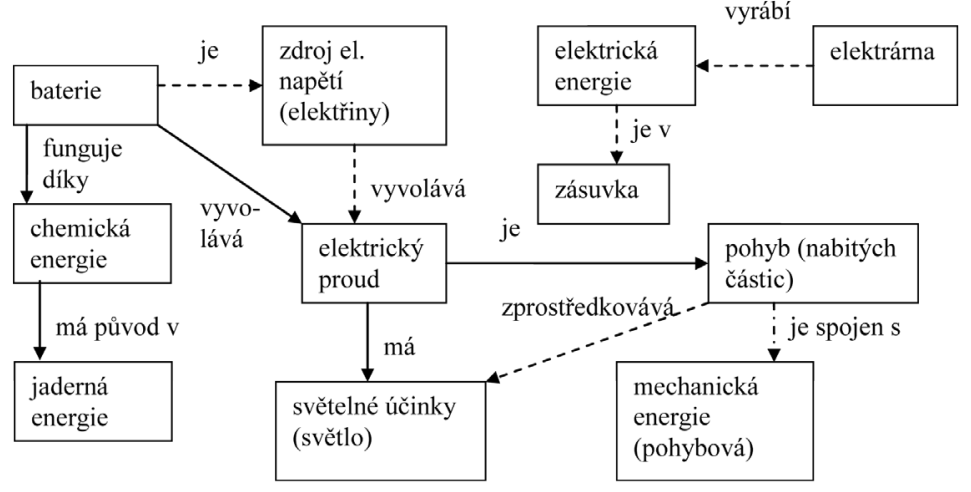

\section{Obrázek 3. Sémanticko-logická sít' pro úlohu 3 - odpovědi A), B)}

Pozn.: Přerušovaně jsou označeny spoje, které mohou a nemusí nastat, nemají však podstatný vliv pro řešení úlohy. Čerchovaně jsou označeny spoje, které jsou bezprostřední příčinou chybného řešení. 
C) chemická - elektrická - světlo (správná odpověd')

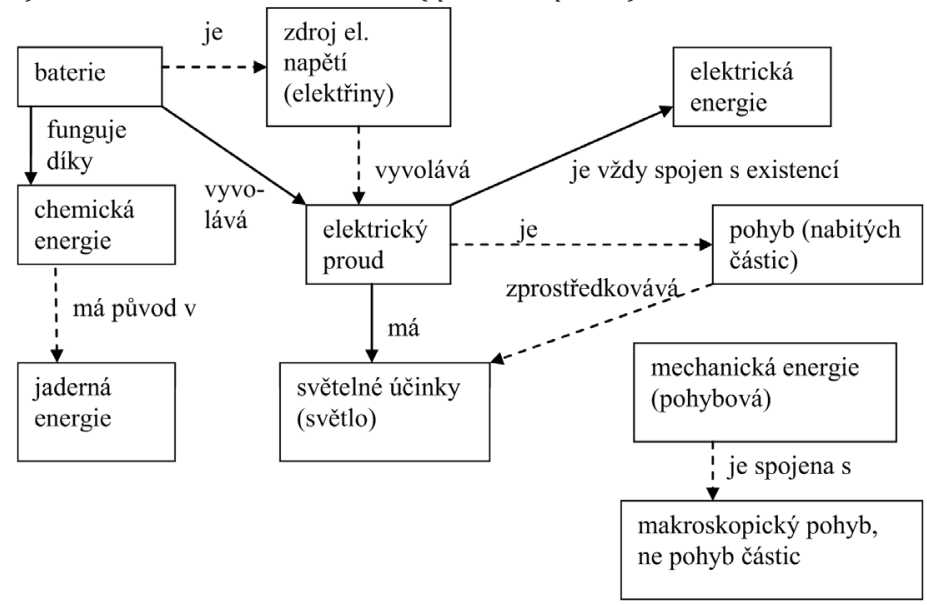

D) jaderná - elektrická - světlo

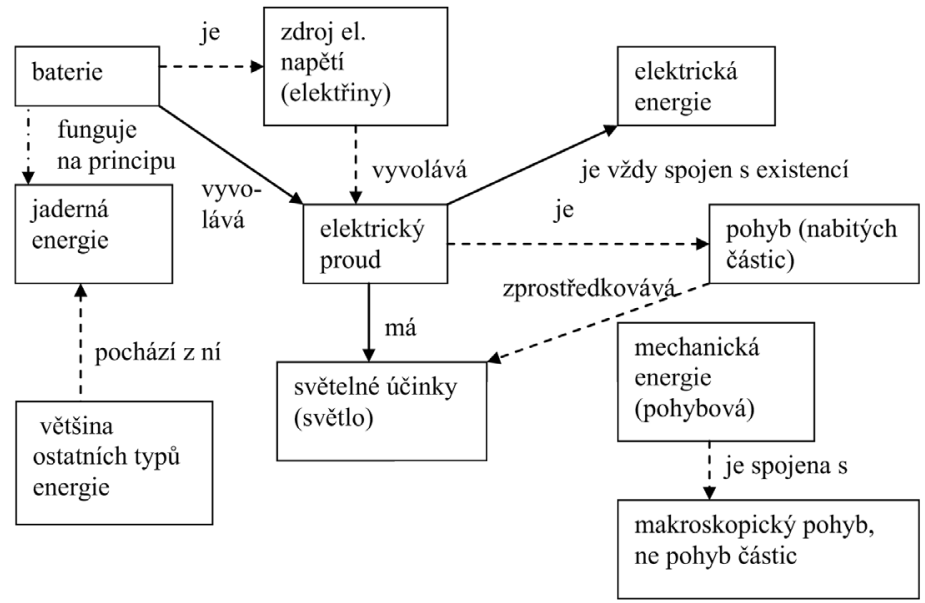

\section{Obrázek 4. Sémanticko-logická sít' pro úlohu 3 - odpovědi C), D)}

Pozn.: Přerušovaně jsou označeny spoje, které mohou a nemusí nastat, nemají však podstatný vliv pro řešení úlohy. Čerchovaně jsou označeny spoje, které jsou bezprostřední příčinou chybného řešení. 
Komentář k úloze 3: U nejčastěji volené možnosti A) (více než 50 \% odpovědí) došlo nejspíše k nesprávnému ztotožnění baterie jakožto zdroje elektrického napětí s elektrickou energií. Dále žáci ze správné úvahy, že elektrický proud je tvořen pohybem nabitých částic, a ze znalosti typů mechanické energie (pohybová a polohová) nesprávně vyvodili, že v přeměně energie bude hrát roli mechanická energie. Neuvědomili si přitom, že mechanická energie je spojena s makroskopickým pohybem a pohyb elektronů jakožto elementárních částic v elektrickém poli tedy neodpovídá mechanické energii. Tento problém nejspíše nastával i u možnosti B), kde však již žáci správně usoudili, že v baterii je základem chemická energie. $V$ této možnosti se nevyskytovala vůbec elektrická energie, což může souviset s tím, že tento druh energie mají někteři žáci spojeni s elektrickou rozvodnou sítí, nikoliv se zdroji, které k této síti nejsou připojeny. Konečně poslední chybnou možnost, D), žáci pravděpodobně volili proto, že si osvojili v učebnicích uváděný poznatek, že původem téměř všech typů energie je jaderná energie ze Slunce. ${ }^{18} \mathrm{Z}$ fyzikálního hlediska vlastně není uvedená odpověd' ani jednoznačně chybná, protože chemická energie $\mathrm{v}$ baterii samozřejmě není výjimkou a vznikla přeměnou $\mathrm{z}$ jaderné energie dodané Sluncem. Standardně se však u žáků rozvíjí provázání baterie s chemickou energií, které odpovídá jejich věku a nahrává i mezipředmětovým souvislostem fyziky a chemie.

Úloha 10: Který z obrázků znázorňuje uspořádání částic v kovu poté, co byl zahřát?

Komentář $k$ úloze 10: Úloha je z fyzikálního pohledu zadána velmi podivně, což dokazuje, že i do mezinárodních srovnání se mohou dostat sporné problémy (např. u státních maturit by podobná úloha určitě vyvolala velké rozepře). Řešení úlohy je potřeba provést ve dvou stupních. V prvním kroku je podstatný empirický poznatek, že objem těles z kovu se při zvýšení teploty zvětšuje (roztahují se koleje apod.). S uvážením tohoto poznatku je možnost B) zjevně chybná (protože by implikovala naopak zmenšení rozměrů s rostoucí teplotou). Zbylé tři možnosti jsou v souladu s makroskopickými projevy teplotní roztažnosti a liší se v tom, co se děje na mikroskopické úrovni. Možnost A) přitom vysvětluje zvětšení rozměrů zvětšením částic, možnost B) souběžným zvětšením částic a vznikem mezer mezi nimi, a konečně možnost D) (správná dle autorů úlohy) pouze vznikem mezer mezi částicemi

18 Přesně tento poznatek byl podstatou úlohy $4, \mathrm{v}$ níž prapůvod energie v potravě ve Slunci odhalilo pouze $18 \%$ žáků. Bylo by zajímavé zjistit korelaci mezi správně vyřešenou úlohou 4 a odpovědí D) v uvažované úloze 3. 
při zachování dané velikosti částic. Uvedená interpretace je z pohledu fyziky pevných látek přinejmenším sporná, protože v zadání je užit tzv. model tuhých koulí (jednotlivé částice vyplňují prostor maximálním možným způsobem - viz Wilkes, 1973), zatímco ve správné odpovědi je tento model popřen, což nelze odůvodnit změnou teploty. ${ }^{19}$ Rovněž argument, že částice při změně teploty nemění svoji velikost, je více než sporný. Pokud bychom se zabývali např́́klad vibracemi částic v krystalové mř́ízi kovu, amplituda těchto vibrací přirozeně roste s rostoucí teplotou, což je zásadní například pro vysvětlení teplotní závislosti elektrického odporu kovů (Kittel, 1985). Vlnová funkce udávající pro daný stav hustotu pravděpodobnosti výskytu částice sice nezávisí explicitně na teplotě, ale zvýšení teploty má za následek změnu v pravděpodobnostech obsazení jednotlivých energetických hladin, což ve svém důsledku vede i ke zvýšení pravděpodobnosti toho, že se daná částice vyskytuje dále od rovnovážné polohy, tj. rozměr částic je větší.

Bez ohledu na to, že zadání úlohy je z pohledu teoretické fyziky zavádějící, se zkusme podívat na problém očima žáků 8. tř́dy a načrtnout sémanticko-logické sítě odpovídající jednotlivým možnostem. Vycházíme přitom z toho, že žáci činí závěry o dění v mikrosvětě na základě své empirické zkušenosti z makrosvěta (tento předpoklad je opodstatněný, protože v 8. třídě se drtivá většina z nich ještě neměla možnost setkat s informacemi o podivných zákonitostech mikrosvěta řízených kvantovou fyzikou). Sítě jsou uvedeny pouze pro možnosti A), C) a D), protože u možnosti B) je chybná již základní úvaha v makrosvětě. Podstatný může být pro úvahy žáků v rámci mikrosvěta poznatek o existenci bimetalu. Ten je založen na tom, že dva různé kovy se při zvětšení teploty roztahují různě. To však může v žácích vyvolat představu, že různé atomy mění svoji velikost různě, a tudíž že se velikost částic mění (není pravděpodobné, že by za příčinu odlišných makroskopických změn velikosti pokládali odlišné formování mezer mezi neměnnými částicemi u různých látek). Naopak, argumentem pro neměnnost velikosti částic může být představa, že atomy jsou základní stavební kameny hmoty, a tyto kameny by tudíž měly být neměnné, a tedy i nezávislé na teplotě. Podobně u vzniku mezer mezi částicemi mohou být podstatné úvahy o tom, že jsou mezery mezi kolejemi, a vlaky tudíž v létě nejezdí tak rychle apod.

19 Př́sně logicky by dokonce bylo možné varianty odpovědí C) a D) uvažující vznik mezer mezi částicemi rovnou vyloučit, protože je-li nějaký fyzikální model uvažován v zadání (byt' to není explicitně řečeno), dalo by se očekávat, že bude stejný model vyžadován i v řešení. Správně by pak musela být možnost A). 
A)

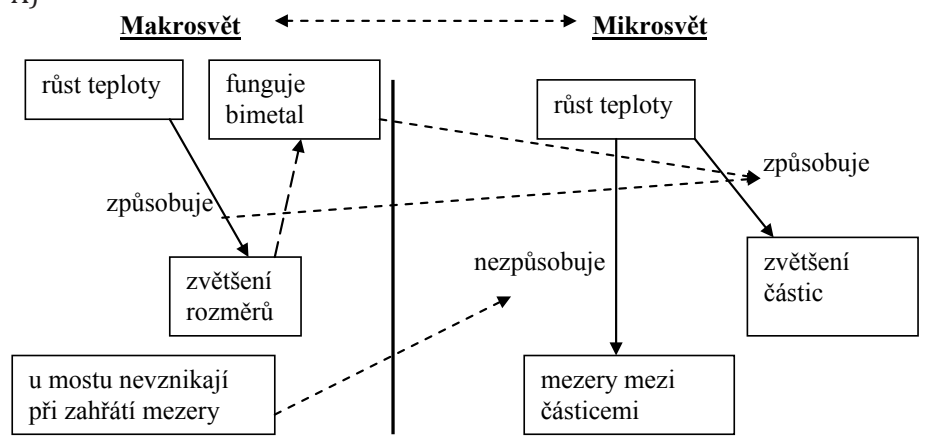

B)
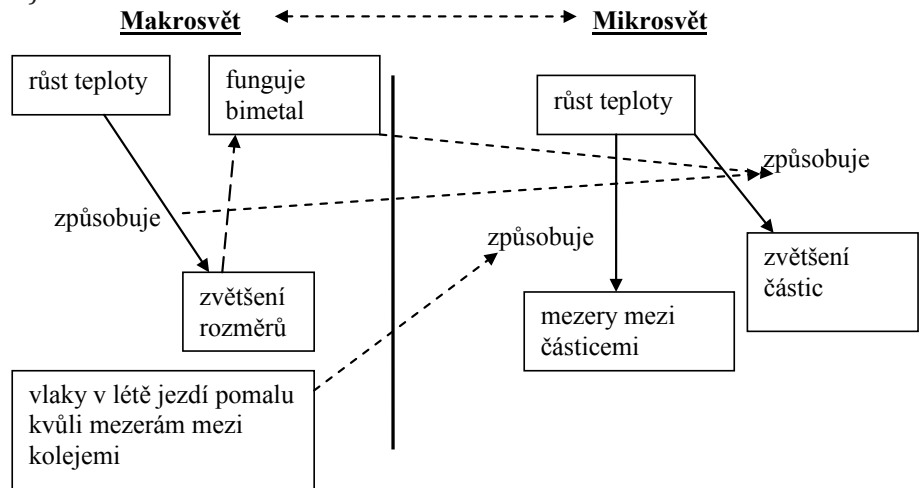

D) správná odpověd' dle autorů úlohy

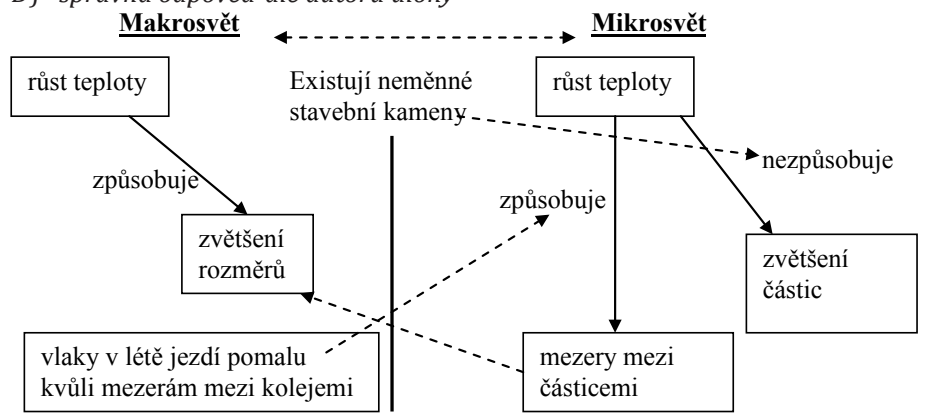

Obrázek 5. Sémanticko-logická sít’ pro úlohu 10 - odpovědi A), B), D) 


\subsection{Identifikace kritických míst na základě problematických úloh a výpovědí učitelu}

V předchozích částech jsme identifikovali příčiny problematických úloh ze šetření TIMSS. Předmětem této části bude na základě uvedených úloh a názorů učitelů zapojených do výzkumného šetření stanovit kritická místa. Vzhledem k tomu, že učitelé byli explicitně tázáni pouze na učivo 6. a 7. ročníku, zaměříme se na tematické celky probírané typicky v těchto ročnících. Jedná se o následující oblasti:

- úvod do fyziky,

- elektřina,

- magnetismus,

- pohyb a síly,

- mechanika tekutin,

- světelné jevy.

Do těchto oblastí patřilo celkem 12 z 19 identifikovaných problematických úloh. ${ }^{20}$ Učitelé byli v rozhovorech žádáni, aby z celkem 80 předložených témat pokrývajících uvedených šest oblastí označili maximálně 10 kritických. ${ }^{21}$ Následně byl zjištěn počet výběrů pro každé z těchto témat. ${ }^{22}$ Pro danou tematickou oblast byl stanoven celkový počet výběrů pro všechna témata do ní spadající a vydělením příslušným počtem témat byla určena její celková kritičnost. ${ }^{23}$ Ta je společně s počty a podíly problematických úloh $v$ dané oblasti uvedena $v$ tabulce 3 .

20 Čtyři úlohy se týkaly tematického celku „energie“, tři úlohy poté „tepelných jevů“. Oba tyto tematické celky se probírají typicky v 1. pololetí 8. ročníku.

21 Učitelé vybírali kritická místa na základě vlastního uvážení a nebyli nijak instruováni, zda mají výběr zaměřit na úspěšnost žáků, náročnost výkladu pro ně samotné či nějaké jiné hledisko. Následný průběh rozhovoru však ukázal, že prakticky ve všech případech učitelé vybírali na základě úspěšnosti žáků.

2218 témat nevybral jako kritická ani jeden učitel, naopak nejčastěji zmiňovaná témata "magnetické indukční čáry“ a „čočky“ uvedlo vždy 10 učitelů.

23 Například u tematické oblasti „magnetismus“ bylo sedm témat, jež byla učiteli vybrána dohromady 26krát. Kritičnost tedy byla stanovena jako 26/7 = 3,72. 
Tabulka 3

Srovnání pohledu učitelů a závěrů z šetření TIMSS

\begin{tabular}{llll}
\hline Tematický celek & $\begin{array}{l}\text { Počet úloh } \\
\text { TIMSS }\end{array}$ & $\begin{array}{l}\text { Počet úloh TIMSS } \\
\text { definovaných jako } \\
\text { problematické }\end{array}$ & $\begin{array}{l}\text { Kritičnost dle } \\
\text { dotazovaných učitelů } \\
\text { (body) }\end{array}$ \\
\hline $\begin{array}{l}\text { Úvod do fyziky } \\
\text { (těleso, látka, veličiny) }\end{array}$ & 10 & 2 & 2,29 \\
\hline Elektřina & 7 & 1 & 2,13 \\
\hline Magnetismus & 5 & 2 & 3,72 \\
\hline Pohyb a síly & 13 & 1 & 2,99 \\
\hline Mechanika tekutin & 10 & 2 & 3 \\
\hline Světelné jevy & 20 & 4 & 2,86 \\
\hline
\end{tabular}

Z uvedené tabulky je patrné, že učitelé jako nejvíce kritický celek hodnotí „magnetismus“, u něhož je zároveň největší podíl problematických úloh. Na opačném konci je „elektřina“" ${ }^{44}$, u níž opět dochází k rámcové shodě v pohledu učitelů a mezinárodního šetření. Ačkoliv uvedený soulad není vzhledem k nízkému počtu úloh v jednotlivých celcích statisticky průkazný, trend naznačující značnou shodu mezi oběma zdroji informací stojí za pozornost.

Z hlediska jednotlivých témat v rámci celků učitelé v případě „magnetismu“ nejčastěji zmiňovali organizační koncept magnetické indukční čáry (10 učitelů) a aplikační koncept elektromagnet (7 učitelů). U jediné analyzované úlohy TIMSS zaměřené na elektromagnet (úloha $1 \mathrm{v}$ tabulce 3 ) přitom byly zaznamenány vůbec nejhorší výsledky v mezinárodním kontextu, když národní průměr byl o 15 procentních bodů horší než mezinárodní. Velmi nízká úspěšnost českých žáků (10 procentních bodů pod mezinárodním průměrem a třetí nejhorší výsledek vůbec) byla zjištěna i u úlohy 2 zaměřené právě na magnetické indukční čáry. Můžeme tak konstatovat, že obě uvedená témata patří mezi kritická.

V rámci „mechaniky tekutin“, vnímané učiteli jako druhý nejkritičtější tematický celek, byly nejčastěji zmiňovány jako kritická místa organizační koncepty Archimédův zákon (9 učitelů) a Pascalův zákon (7 učitelů). Porovnání s úlohami TIMSS zde není bohužel možné, protože nebyly identifikovány žádné úlohy zaměřené na tato témata. Navzdory tomu se na základě

24 Tento výsledek je na první pohled překvapivý. Je však třeba si uvědomit, že náročné pasáže z elektřiny se probírají typicky až v 2. pololetí 8. ročníku a v 1 . pololetí 9. ročníku, a tudíž nebyly předmětem našeho srovnání. 
dalších analýz domníváme, že se jedná o kritická místa, jimž by měla být věnována pozornost.

Učitelé úplně nejčastěji zmiňovali jako kritické místo substantivní koncept hustota (12 učitelů). To je v souladu se závěry z šetření TIMSS, kde se jediná analyzovaná úloha zabývající se hustotou (úloha 11) vyznačovala nižší úspěšností ve srovnání s mezinárodním průměrem. Hustotu tak rovněž můžeme pokládat za kritické místo kurikula, což je v souladu s poznatky z literatury (Dvořáková, 2015). Konečně poměrně značný počet problematických úloh byl zjištěn v tematickém celku „světelné jevy“. Učitelé z této oblasti nejčastěji identifikovali jako kritické místo aplikační koncept zobrazení čočkami (10 učitelů). Ačkoliv žádná úloha z šetření TIMSS se explicitně tímto tématem nezabývala, existence hned několika souvisejících miskoncepcí popsaných v literatuře (Mandíková \& Trna, 2011) nás vedly $\mathrm{k}$ tomu uvedené téma rovněž zařadit jako kritické. Žádné další téma ze 6. a 7. ročníku již při uvážení pohledu učitelů a výsledků úloh ze šetření TIMSS nesplnilo podmínky pro jeho identifikaci jako kritického místa. Do skupiny kritických míst tak spadají následující témata:

- hustota,

- magnetické pole a magnetické indukční čáry,

- elektromagnet,

- Pascalův zákon,

- Archimédův zákon,

- zobrazování čočkami.

\section{Diskuze a závěr}

Studie byla zaměřena na identifikaci a didaktickou analýzu úloh z fyziky z testování přírodovědné gramotnosti v rámci mezinárodního šetření TIMSS v letech 1995, 1999 a 2007. Bylo analyzováno celkem 99 úloh a na základě jasně stanovených kritérií bylo za problematické označeno celkem 19 z nich. S pomocí polostrukturovaných rozhovorů s 31 učiteli základních škol, analýz ŠVP, učebnic a hodinových dotací fyziky v jednotlivých ročnících základních škol byly odhadnuty příčiny problematičnosti těchto úloh. V dalším kroku byla v souladu se stanovenou výzkumnou otázkou a na základě uvedených 
problematických úloh, resp. rozhovorů s učiteli vymezena kritická místa. Tato kritická místa přitom mohou být chápana jako fyzikální koncepty mající jasnou hierarchii (klíčové, substantivní, organizační a aplikační koncepty). Díky popsanému prrístupu bylo možné získat jasnou představu o příčinách a souvislostech zmíněné kritičnosti, jež je zásadní pro hledání cest $\mathrm{k}$ řešení problému.

Naše studie má přirozeně určité limity dané jejím designem a možnostmi analýzy. Předně byla identifikace příčin kritičnosti stejně jako tvorba sémanticko-logických sítí provedena převážně z ontodidaktické pozice bez př́mého zapojení žáků či rozboru jejich prací do výzkumu. Vycházíme sice z psychodidaktických informací o výsledcích řešení testových úloh, ale u analýzy úloh pak spoléháme jen na ontodidaktické hledisko, tedy bez dalšího psychodidaktického zkoumání konkrétních miskoncepcí způsobujících hromadné chybování během procesu řešení úlohy. Do budoucna by bylo určitě vhodné ověřit validitu uvedených zjištění pomocí výzkumu soustředěného přímo na žáky. Na druhé straně jsme přesvědčeni o tom, že ontodidaktický rozbor testových úloh opřený o zjištěné výsledky bývá opomíjený a je nezbytným východiskem pro porozumění možným př́činám žákovského chybování, např. vzhledem k složitosti úlohy, nejasnosti zadání nebo nabízených odpovědí apod. Proto si zasluhuje zvláštní pozornost.

Dalším limitem naší studie může být, že úlohy z TIMSS pocházejí z let 1995, 1999 a 2007 (později se již ČR v námi sledovaném 8. ročníku ZŠ do šetření nezapojila), a jsou tak poněkud staršího data. Není však vážný důvod se domnívat, že se kritičnost témat a její příčiny v posledních letech nějak dramaticky změnily. Konečně je třeba uvážit, že úspěšnost v dané úloze napříč různými státy může být ovlivněna konkrétní formulací úlohy v dané jazykové verzi, užitou terminologií (to bylo vidět u úlohy 5 , v níž byl použit na českých ZŠ nezvyklý pojem kinetická energie) apod. Tyto faktory mohou srovnatelnost výsledků šetření na úrovni jednotlivých úloh negativně ovlivnit. Určitou roli mohl sehrát rovněž výběr učitelů pro polostrukturované rozhovory, jenž byl realizován v rámci projektu, a zahrnul tak učitele, kteří se o danou problematiku zajímají pravděpodobně více, než odpovídá průměru.

Na základě provedených analýz jsme přesvědčeni, že příčiny kritičnosti se týkají jak psychodidaktických, tak i ontodidaktických hledisek a vycházejí z rozmanitých zdrojů. Pokud jde o psychodidaktickou stránku věci, je vhodné další výzkum centrovat na žáky a provázat jej s problematikou 
prekoncepcí - s utvářením a uplatňováním žákovských představ. V této souvislosti se poté dostávají do popředí zájmu výukové strategie cílené na překonání chybných prekoncepcí, jež byly detailně diskutovány např. Mandíkovou a Trnou (2011). Bylo by zajímavé věnovat větší pozornost i příčinám toho, proč žáci dosahují v uzavřených úlohách lepších výsledků ve srovnání s úlohami otevřenými. Souhlasíme s názorem Rendla a Vondrové (2014), že uzavřené úlohy podstatně limitují druhy možných chyb a mohou vést $\mathrm{k}$ tomu, že je za častou chybu považována odpověd', která by byla bez výběru odpovědí označována jen velmi zř́́dka.

Z ontodidaktického hlediska se zde otevírá prostor směrem k případným změnám kurikulárních dokumentů vedoucím například k lepší provázanosti učiva matematiky a fyziky, resp. $\mathrm{k}$ důslednějšímu zohlednění hodinové dotace fyziky při tvorbě ŠVP. ${ }^{25}$ I z tohoto důvodu se domníváme, že předkládaná studie přináší díky zacílení na jasně definovaná kritická místa kurikula (a jim odpovídající typy problematických úloh) relevantní poznatky mající potenciálně dopad i do oblasti v současné době realizované reformy rámcových vzdělávacích programů. Při její přípravě a následné implementaci do praxe by bylo vhodné zohlednit to, jak přistupují k výuce identifikovaných kritických míst v zemích, jež ve sledovaných úlohách dosahovaly podstatně lepších výsledků ve srovnání s ČR. Podrobnější zkoumání toho, jak k těmto (v rámci ČR) kritickým místům přistupují v zahraničí, a hledání příkladů dobré praxe a zdrojů inspirace by pak mohlo být rovněž předmětem dalšího výzkumu $\mathrm{v}$ této oblasti.

\section{Literatura}

Anderson, R. C., \& Pearson, P. D. (1984). A schema-theoretic view of basic processes in reading. In P. D. Pearson (Ed.), Handbook of Reading Research (s. 255-291). New York: Longman.

Beichner, R. J. (2009). An introduction to physics education research. In C. Henderson \& K. A. Harper (Eds.), Getting started in physics education research (s. 25-49). American Association of Physics Teachers: College Park. Dostupné z http://www.percentral.org/ items/detail.cfm?ID=8806

Dvořák, D. (2009). Řazení učiva v soudobých teoriích kurikula. Pedagogika, 59(2), 136-152.

Zde se nabízí např́íklad možnost přesunout ve školách s jednou hodinou fyziky v 6. ročníku téma „hustota“ do 7. ročníku a tam jej organicky propojit s tématem „Archimédův zákon“ či přesunout učivo o „elektromagnetu“ do 9. ročníku a provázat jej s učivem o „elektromagnetické indukci“, což by ostatně lépe odráželo vzájemný vztah elektřiny a magnetismu. 
Dvořáková, I. (2015). Kostkovaná hustota. In V. Koudelková (Ed.), Sborník z konference Veletrh nápadů učitelů fyziky 20. Praha: P3K. Dostupné z http://vnuf.cz/sbornik/rocniky/ Praha-2015_(20).html

Goodman, N., \& Elginová, Z. E. (2017). Nové pojetí filozofie a dalších umění a věd. Praha: Univerzita Karlova - Filozofická fakulta.

Hejný, M. (2008). Scheme-oriented educational strategy in Mathematics. In B. Maj, M. Pytlak, \& E. Swoboda (Eds.), Supporting Independent Thinking Through Mathematical Education. Proceedings of CME 08 Conference (s. 40-48). Rzeszow: Nawa Era.

Hewitt, P. G. (1971). Conceptual physics: a new introduction to your environment. Little Brown: Boston.

Höfer, G., Půlpán, Z., \& Svoboda, E. (2005). Výuka fyziky v širších souvislostech (názory žáků). Plzeň: Západočeská univerzita v Plzni. Dostupné z https://kdf.mff.cuni.cz/vyzkum/ materialy/vyuka_fyziky_v_sirsich_souvislostech.pdf

Janík, T., \& Slavík, J. (2009). Obsah, subjekt a intersubjektivita v oborových didaktikách. Pedagogika, 59(2), 116-135.

Kaščák, O., \& Pupala, B. (2011). PISA v kritickej perspektíve. Orbis Scholae, 5(1), 53-70.

Kittel, C. (1985). Úvod do fyziky pevných látek. Praha: Academia.

Kohout, J., Mollerová, M., Masopust, P., Feřt, L., Kéhar, O., \& Slavík, J. (2018). Kritická místa ve výuce fyziky na ZŠ - úvod do problematiky a možnosti výzkumu. Arnica, 8(1), 26-34.

Kvasz, L. (2015). Inštrumentálny realizmus. Pavel Mervart: Červený Kostelec.

Lancor, R. (2014). Using metaphor theory to examine conceptions of energy in biology, chemistry, and physics. Science \& Education, 23(6), 1245-1267.

Maňák, J. (2007). Modelování kurikula. Orbis scholae, 2(1), 40-53.

Mandíková, D., \& Trna, J. (2011). Žákovské prekoncepce ve výuce fyziky. Brno: Paido.

Mentlík, P., Slavík, J., \& Coufalová, J. (2018). Kritická místa kurikula, organizační a klíčové koncepty - konceptuální vymezení a př́klady z výuky geověd. Arnica, 8(1), 9-18.

Mollerová, M., Kohout, J., Feřt, L., \& Masopust, P. (2018). Nedostatek aprobovaných učitelů fyziky na západě Čech: bude hůr. Matematika-fyzika-informatika, 27(1), 46-54.

Palečková, J., Straková, J., \& Tomášek, V. (1997). Třetí mezinárodní výzkum matematického a prrírodovědného vzdělávání - výsledky žáků 7. a 8. ročníků: př́rodovědné predměty. Praha: Ústav pro informace ve vzdělávání.

Rendl, M., \& Vondrová, N. (2014). Kritická místa v matematice u českých žáků na základě výsledků šetření TIMSS 2007. Pedagogická orientace, 24(1), 22-57.

Rendl, M., Vondrová, N., Hříbková, L., Jirotková, D., Kloboučková, J., Kvasz, L., \& Žalská, J. (2013). Kritická místa matematiky na základní škole očima učitelů. Praha: Univerzita Karlova.

Slavík, J., Janík, T., Najvar, P., \& Knecht, P. (2017). Transdisciplinární didaktika: o učitelském sdílení znalostí a zvyšování kvality výuky např́ic obory. Brno: Masarykova univerzita.

Straková, J. (2011). Ke kritice výzkumu PISA. Orbis scholae, 5(3), 123-127.

Straková, J. (2016). Mezinárodní výzkumy výsledků vzdělávání: metodologie, př́nosy, rizika a prŕležitosti. Praha: Univerzita Karlova.

Strawson, P. F. (1997). Indivíduá. Esej o deskriptívnej metafyzike. Bratislava: Iris.

Štech, S. (2015). Proč se kritizuje PISA? Pedagogická orientace, 25(4), 605-612. 
Štěpáník, S., \& Slavík, J. (2017). Žákovské prekoncepty jako konstitutivní prvek výuky mateřského jazyka. Pedagogická orientace, 27(1), 58-80.

Švaříček, R., Šed’ová, K., Janík, T., Kaščák, O., Miková, M., Nedbálková, K. (...) Zounek, J. (2007). Kvalitativní výzkum v pedagogických vědách. Praha: Portál.

Tomášek, V., \& Mandíková, D. (2009). Výsledky českých žáků ve výzkumu TIMSS 2007. Matematika-fyzika-informatika, 19(5), 275-291.

Tomášek, V., Frýzková, M., Janoušková, S., Mandíková, D., Palečková, J., \& Švejdová, D. (2009). Výzkum TIMSS 2007: Úlohy z prírodních věd pro 8. ročník. Praha: Ústav pro informace ve vzdělávání. Dostupné z https://www.csicr.cz/getattachment/cz/0-nas/Mezinarodnisetreni-archiv/TIMSS/TIMSS-2007/Ulohy-z-PV-8-roc-publikace.pdf

ÚIV. (2001). Úlohy z matematiky a př́rodních věd pro žáky 8. ročníku: třetí mezinárodní výzkum matematického a př́rodního vzdělávání: replikace 1999. Praha: Ústav pro informace ve vzdělávání. Dostupné z http://www.csicr.cz/getattachment/cz/O-nas/Mezinarodnisetreniarchiv/TIMSS/TIMSS-1999/matematicke-a-prirodovedne-ulohy.pdf

Vondrová, N., \& Rendl, M. (2017). Kritická místa matematiky základní školy v řešeních žáků. Praha: Univerzita Karlova.

Wilkes, P. (1973). Solid state theory in metallurgy. Cambridge: Cambridge University Press.

\section{Autoři}

Mgr. Jiří Kohout, Ph.D., Západočeská univerzita v Plzni, Fakulta pedagogická,

Katedra matematiky, fyziky a technické výchovy, Oddělení fyziky, Klatovská 51, 30100 Plzeň,

Česká republika; e-mail: jkohout4@kmt.zcu.cz

Mgr. Marie Mollerová, Západočeská univerzita v Plzni, Fakulta pedagogická,

Katedra matematiky, fyziky a technické výchovy, Oddělení fyziky, Klatovská 51, 30100 Plzeň,

Česká republika; e-mail: maruska@cbg.zcu.cz

PhDr. Pavel Masopust, Ph.D., Západočeská univerzita v Plzni, Fakulta pedagogická,

Katedra matematiky, fyziky a technické výchovy, Oddělení fyziky, Klatovská 51, 30100 Plzeň,

Česká republika; e-mail: pmasop@kmt.zcu.cz

Mgr. Lukáš Feřt, Západočeská univerzita v Plzni, Fakulta pedagogická, Katedra matematiky, fyziky a technické výchovy, Oddělení fyziky, Klatovská 51, 30100 Plzeň, Česká republika;

e-mail: lfert@kmt.zcu.cz

doc. PaedDr. Jan Slavík, CSc., Západočeská univerzita v Plzni, Fakulta pedagogická,

Katedra pedagogiky, Klatovská 51, 30100 Plzeň, Česká republika; e-mail: slavikj@kvk.zcu.cz 


\title{
Critical spots of curriculum in lower-secondary education from the point of view of international assessment TIMSS and the Czech teachers - findings from physics
}

\begin{abstract}
The aim of this study is to determine which tasks belonging to cognitive domain Physics in TIMSS carried out in 1995, 1999 and 2007 are problematical in terms of low results of Czech students in comparison with international average, to estimate the causes of these results, and to determine the crtitical spots of lower-secondary physics curriculum. The current state-of-the-art in the field of research on critical spots of curriculum is briefly outlined in the introductory part. The critical spots are defined as the problems with the physical concepts during teaching and learning whose hierarchy is described and discussed. Subsequently, the criteria for identification of 19 problematical tasks used in the TIMSS are given. Moreover, the research aiming to identify the causes of the below-averaged results (analysis of the relevant curriculum documents and the interviews with 31 secondary-school physics teachers) is presented. We have also outlined semantic and logic networks providing a deeper insight into the mental processes of the students hidden behind the solution for three selected tasks. Six critical spots of curriculum of physics education in the lower-secondary schools have been identified. It was shown that the causes of the criticality may be found in the psychodidactical as well as the ontodidactical area. The presented findings suggest that significant attention should be devoted to further research in this field and particularly the development of techniques how to eliminate the critical areas determined in this study. The causes of the criticality as well as the hierarchy of the concepts should be taken into consideration in the reform of the curriculum documents.
\end{abstract}

Key words: critical spots of curriculum, international assessment, TIMSS, interviews, problematical tasks, physics teachers, semantic and logic networks 